\title{
Long Term Prediction of Unconventional Oil Production
}

\author{
S. H. Mohr* \\ G. M. Evans \\ University of Newcastle, Faculty of Engineering and Built Environment, Chemical Engineering, \\ University Drive, Callaghan, NSW 2308, Australia
}

\begin{abstract}
Although considerable discussion surrounds unconventional oil's ability to mitigate the effects of peaking conventional oil production, very few models of unconventional oil production exist. The aim of this article was to project unconventional oil production to determine how significant its production may be. Two models were developed to predict the unconventional oil production, one model for in-situ production and the other for mining the resources. Unconventional oil production is anticipated to reach between 18 and $32 \mathrm{~Gb} / \mathrm{y}(49-88 \mathrm{Mb} / \mathrm{d}$ ) in 2076-2084, before declining. If conventional oil production is at peak production then projected unconventional oil production cannot mitigate peaking of conventional oil alone.
\end{abstract}

Key words: Unconventional oil, Modeling, Supply

\section{Introduction}

There is increasing certainty that conventional oil ${ }^{1}$ production has peaked/will peak before 2025 e.g. Aleklett (2004); Bakhtiari (2004); Deffeyes (2002); Mohr and Evans (2007, 2008); Wells (2005a,b). Given the likely peak in conventional

\footnotetext{
${ }^{*}$ Corresponding author.

Email addresses: steve.mohrestudentmail. newcast le.edu.au (S. H. Mohr), Geoffrey.Evans@newcastle.edu.au (G. M. Evans)

${ }^{1}$ Conventional oil will be considered to be hydrocarbons which at atmospheric condition are liquid and have a density less than water (API $>10^{\circ}$ ). Conventional oil includes natural gas liquids, deep water oil and heavy oil (density $10-20^{\circ}$ API).
} 
oil production, it is important to examine unconventional oil resources and possible production. Literature models on unconventional oil production are variable. Edwards (1997) modeled Canadian tar sands, US Shale oil, and Venezuelan Extra Heavy oil and indicated combined production approaching $10 \mathrm{~Gb} / \mathrm{y}(\sim 25 \mathrm{Mb} / \mathrm{d})$ by 2100 . Koppelaar (2007) has unconventional oil reaching a plateau of $4.5 \mathrm{~Gb} / \mathrm{y}$ (12.5 Mb/d). Söderbergh et al. (2007) indicates Canadian natural bitumen production reaching a peak of $2.2 \mathrm{~Gb} / \mathrm{y}(6 \mathrm{Mb} / \mathrm{d})$ in 2040. Söderbergh et al. (2007) model takes into account factors such as the energy required to extract and process the natural bitumen and the accessibility of the resource, and has been peer reviewed. Contradicting the estimates from Edwards (1997); Koppelaar (2007); Söderbergh et al. (2007) is Caruso (2005) who indicates that Canadian natural bitumen alone will reach a peak of $41 \mathrm{~Gb} / \mathrm{y}(112 \mathrm{Mb} / \mathrm{d}$ ) in 2078 (and $\sim 8 \mathrm{~Gb} / \mathrm{y}$ or $22 \mathrm{Mb} / \mathrm{d}$ in 2050). The work by Caruso (2005) is simplistic with the assumption that Canadian unconventional oil continues to grow at $6 \%$ until 2078 and then decline at the same rate. For these reasons, the work by Söderbergh et al. (2007) has been given higher weighting than that by Caruso (2005). The question therefore to be addressed here is assuming conventional oil production will peak before 2025, what role can unconventional oil have? Specifically is it the case that unconventional oil production can provide a smooth transition when conventional oil peaks, is unconventional oil insignificant compared to conventional oil production or is unconventional oil production significant but too late to mitigate short term effects of conventional oil production peaking?

A critical assessment of unconventional oil resources, and a model of unconventional oil production is developed to determine if unconventional oil can mitigate the effects of conventional oil production peaking. Unconventional oil is limited to extra heavy oil, natural bitumen (oil sands, tar sands) and oil shale, other fuels such as coal and natural gas are not considered as unconventional oil as they are valuable in their original state and hence not likely to be used as major sources of synthetic crude production. Extra Heavy oil is defined as a hydrocarbon with an API of $<10^{\circ}$ and a viscosity of $<10,000 \mathrm{cP}$ WEC (2007). Natural Bitumen has a density $<10^{\circ}$ API, the same as Extra heavy oil, but is more viscous than Extra Heavy oil (typically stated as > 10, 000 cP WEC (2007); Meyer (1998)). Oil shale is kerogen typically in marlstone, it is typically neither a shale nor an oil. A synthetic conventional oil (called shale oil) can be generated by processing the oil shale. The Ultimately Recoverable Resources (URR) reported here refers to the total amount of synthetic crude oil extracted from the resource i.e. natural bitumen, extra heavy oil, shale oil.

The aim of the study is to predict unconventional oil production. First, a supply 
model is developed which includes in-situ and mining extraction techniques. Second the model is calibrated based on historical Canadian natural bitumen production and "Pessimistic", "Optimistic" and "Best guess" URR scenarios determined. Finally the model outputs are combined with previously reported conventional oil analysis to obtain combined oil production projections.

\section{Model description}

\section{Mining production}

The unconventional oil model is based on previous work Mohr and Evans (2009) applied to coal production. Briefly the coal production model was based on an individual mine production, with a maximum production, mine life and a 4 year ramp up and down. For a given mine the production profile is shown in Figure 1

\section{Figure 1 hereabouts}

Production for a mining basin, is determined by the sum of the individual mines currently on-line in the basin. Mathematically the production from the $b$-th basin from the mining model $\left(P^{M b}(t)\right)$ is shown in equation 1

$$
P^{M b}(t)=\sum_{l=1}^{n^{M b}(t)} P_{l}^{M b}(t)
$$

where $n^{M b}(t)$ is the number of mines on-line at year $t$ in the $b$-th basin and $P_{l}^{M b}(t)$ is the production of the $l$-th mine in the $b$-th basin. The production profile of a mine $P_{l}^{M b}(t)$ is shown in Figure 1.

The number of mines on-line at time $t, n^{M b}(t)$ depend on the cumulative production so that:

$$
n^{M b}(t)=\left[N^{M b}+\left(1-N^{M b}\right) \exp \left[-k^{M b}\left(\frac{\sum_{l=1}^{n^{M b}(t-1)} C_{l}^{M b}(t)}{U R R^{M b}}\right)\right]\right], \quad t \geq t^{M b}
$$

Where $n^{M b}(t)$ is the number of mines on-line, $N^{M b}$ is the total number of mines, $k^{M b}$ is the proportionate constant, $C_{l}^{M b}(t)$ is the cumulative production of the $l$-th mine at time $t, t^{M b}$ is the year the basin came on-line and $U R R^{M b}$ is the mining ultimately recoverable resources in the $b$-th basin. 


\section{In-situ production}

The in-situ model is identical to the mining model, only instead of production from a mine, production is from a SAGD/CSS plant. The production profile of a SAGD/CSS plant is shown schematically in Figure 2.

Figure 2 hereabouts

It can be seen that a SAGD/CSS plant has a ramp up phase, a maximum production, $p_{M}$ and a decline period.

As with the mining model, the production from the $b$-th basin, $P^{I b}(t)$ in the in-situ model is shown in equation 3

$$
P^{I b}(t)=\sum_{l=1}^{n_{S}^{I b}(t)} P_{l}^{I b}(t)
$$

Where $n_{S}^{I b}(t)$ is the number of SAGD/CSS plants on-line in year $t, n_{w l}^{I b}(t)$ is the number of wells on-line in the $l$-th SAGD/CSS plant, and $P_{l}^{I b}(t)$ is the production from the $l$-th SAGD/CSS plant.

Again, like the mining model, the number of SAGD/CSS plants on-line in the $b$-th basin $\left(n_{S}^{I b}(t)\right)$ is determined from equation 4

$$
n_{S}^{I b}(t)=\left\lceil N_{S}^{I b}+\left(1-N_{S}^{I b}\right) \exp \left[-k_{S}^{I b}\left(\frac{\sum_{l=0}^{n_{S}^{I b}(t-1)} C_{l}^{I b o}(t)}{U R R^{I b}}\right)\right]\right]
$$

where $N_{S}^{I b}(t)$ is the total number of SAGD/CSS plants in the $t$-th year, $C_{l}^{I b o}(t)$ is the cumulative in-situ production from the $l$-th SAGD/CSS plant, $k_{S}^{I b}$ is a proportionality constant and $U R R^{I b}$ is the in-situ ultimately recoverable resources; and are all variables for the $b$-th basin.

Now it is necessary to describe the production from a SAGD/CSS plant. As shown in Figure 2, the production of an individual SAGD/CSS plant, is calculated as the sum of the production from the individual wells in the plant, or mathematically:

$$
P_{l}^{I b}(t)=\sum_{i=1}^{n_{w l}^{I b}(t)} P_{l i}^{I b}(t)
$$

Where $P_{l i}^{I b}(t)$ is the production from the $i$-th well in the $l$-th SAGD/CSS plant and $n_{w l}^{I b}(t)$ is the number of wells on-line at time $t$. The number of wells on-line is 
determined from equation 6

$$
n_{w l}^{I b}(t)=\left[N_{w l}^{I b}+\left(1-N_{w l}^{I b}\right) \exp \left[-k_{w l}^{I b}\left(\frac{\sum_{i=1}^{n_{w l}^{I b}(t-1)} C_{l i}^{I b o}(t)}{U R R_{l}^{I b}}\right)\right]\right], \quad t \geq t_{l}^{I b}
$$

Where $N_{w l}^{I b}$, is the total number of wells, $k_{w l}^{I b}$ is the proportionality constant, $C_{l i}^{I b o}(t)$ is the cumulative production of oil at time $t$ from the $i$-th well and $U R R_{l}^{I b}$ is the Ultimately Recoverable Resources, and all of these terms are for the $l$-th SAGD/CSS plant, in the $b$-th basin. Note at times to keep production below the maximum production $p_{m}$, equation 6 only puts a new well on-line if there is a sufficient gap between actual production and the maximum allowed production.

The only thing left in order to determine production from the in-situ model, is an expression for the production from a well. First, assume that production is proportionate to pressure then

$$
\frac{d C_{l i}^{I b o}(t)}{d t}=K_{l i}^{I b} P r_{l i}^{I b} f_{l i}^{I b o}(t)
$$

where $\operatorname{Pr}_{l i}^{I b}$ is the pressure in the well, $f_{l i}^{I b o}(t)$ is the fraction of oil in the well at time $t, K_{l i}^{I b}$ is the proportionate constant and $C_{l i}^{I b o}(t)$ is the cumulative production of oil from the well at time $t$, all of these variables are for the $i$-th well of the $l$-th SAGD/CSS plant, in the $b$-th basin.

It will be assumed that all wells have the same initial production rate, $p_{0}$. Let $P_{l i}^{I b}(t)$ denote the production as a function of time in the $i$-th well in the $l$-th SAGD/CSS plant in the $b$-th basin, and $t_{l i}^{I b}$ denote the year the well came online. When $t=t_{l i}^{I b}$ then $\frac{d C_{l i}^{I b o}(t)}{d t}=P_{l i}^{I b}\left(t_{l i}^{I b}\right)=p_{0}$, and $f_{l i}^{I b o}\left(t_{l i}^{I b}\right)=1$, hence $K_{l i}^{I b}=p_{0} / P r_{l i}^{I b}$, and so Equation 7 becomes

$$
\frac{d C_{l i}^{I b o}(t)}{d t}=p_{0} f_{l i}^{I b o}(t)
$$

It is assumed that the fraction of oil produced is directly proportionate to the amount of oil and steam in the reservoir hence

$$
f_{l i}^{I b o}(t)=\frac{U R R_{l i}^{I b}-C_{l i}^{I b o}(t)}{U R R_{l i}^{I b}-C_{l i}^{I b o}(t)+C_{l i}^{I b w}(t)}
$$


where $C_{l i}^{I b w}(t)$ is the cumulative amount of water at time $t$, and $U R R_{l i}^{I b}$ is the Ultimately Recoverable Resources, all variables are for the $i$-th well of the $l$-th SAGD/CSS plant in the $b$-th basin. If the pressure is assumed constant, and related to the amount of oil and water in the reservoir, then it is assumed that $C_{l i}^{I b w}=C_{l i}^{I b o}$ and by combining equation 8 and 9 obtain

$$
\frac{d C_{l i}^{I b o}(t)}{d t}=p_{0} \frac{U R R_{l i}^{I b}-C_{l i}^{I b o}}{U R R_{l i}^{I b}}
$$

Assuming the $i$-th well in the $l$-th SAGD/CSS plant in the $b$-th basin, begins in the year $t_{l i}^{I b}$ then

$$
C_{l i}^{I b o}(t)=U R R_{l i}^{I b}-U R R_{l i}^{I b} e^{-\frac{p_{0}}{U R R_{l i}^{I b}}\left(t-t_{l i}^{I b}\right)} .
$$

By differentiating, equation 11 becomes

$$
P_{l i}^{I b}(t)=p_{0} e^{-\frac{p_{0}}{U R R_{l i}^{I b}}\left(t-t_{l i}^{I b}\right)}
$$

and the in-situ model is fully described. More detailed SAGD/CSS models exist e.g. Akin (2005) however the method described here is sufficient.

\section{Model Calibration}

\section{URR estimate}

Resource estimates are well known with general agreement (Russell, 1990; WEC, 2007). However, estimates for URR values are less certain (e.g. Bartis et al. (2005) has Green River Basin URR estimates of $500-1100 \mathrm{~Gb}$ ) and for this reason three scenarios have been selected for analysis, namely Pessimistic, Optimistic and Best Guess. The Pessimistic scenario will assume a low end URR estimate, the Optimistic estimate will assumed high URR predictions, and the Best Guess will be the Authors best guess. Wherever possible the URR was determined from literature estimates as indicated in Tables $1-3$. Where a literature estimate was not known then the URR was assumed to be: (1) $15 \%$ of resources for natural bitumen and extra heavy oil; and (2) $64 \%$ for shale oil. The assumption of $15 \%$ for natural bitumen and extra heavy oil was based on Meyer (1998) indicating 10\%; Ali (2003) and Williams (2003) indicating 15\% and Moritis (2005) indicating $20 \%$. The assumption of $64 \%$ for shale oil was based on Bartis et al. (2005) estimate of the recovery percent for the Green River Basin, which dominates the 
worldwide oil shale resources. The estimate of $64 \%$ recovery for shale oil is very optimistic and will most likely over estimate reality. Tables $1-3$ show the resources and URR values assumed.

Tables $1-3$ hereabouts

SAGD plant operating conditions

Figure 3 hereabouts

The constants for the in-situ model will be simplified by assuming that the proportionality constants for the number of SAGD/CSS plants, and the number of wells in the SAGD/CSS plant are constant for all basins $\left(k_{S}^{I b}=k_{S}, k_{w l}^{I b}=k_{w}\right)$ and all SAGD/CSS plants are the same size $\left(U R R_{l}^{I b}=U R R_{l}^{I}\right)$ for all basins and SAGD/CSS plants. In Figure 3 we have actual production data for the JACOS SAGD plant, by observing production for the first 2 wells, we see that production took 6 months to reach a maximum before beginning to decline. We see that initial production for the two wells was slightly less than $1 \mathrm{Mb} / \mathrm{y}$ hence the initial production of a well $\left(p_{0}\right)$ was set at $0.0005 \mathrm{~Gb} / \mathrm{y}$. Figure 3 indicates that, there was a total of 15 wells brought on-line and the URR for the 15 wells was estimated at 0.025 $\mathrm{Gb}$ (best fit to the data) and the rate constant for the number of wells $k_{w}$ was set at 10 (best fit to the number of wells data, $R^{2}=0.93$ ). The total number of wells for each SAGD/CSS plant for a given basin $b$ was determined by scaling the numbers used to model the JACOS plant so, $N_{w l}^{I b}=(15 / 0.025) U R R_{l}^{I}=600 U R R_{l}^{I}$. All SAGD/CSS plants are assumed to have the same operating parameters (maximum production $p_{M}=72 \mathrm{~kb} / \mathrm{d}, 40$ year lifespan) as the recent Nexen Long Lake plant Long Lake (2009). The rate constant for the number of SAGD/CSS operations $k_{S}$ was determined to be 7 by fitting the model to the Canadian In-situ production $\left(R^{2}=0.98\right)$. Figure 4 shows the comparison between the model and the data for In-situ Canadian production. The constants for the in-situ model for all basins are shown in Tables 4 and 5.

Figure 4 and Tables 4 and 5 hereabouts

\section{Mine operating conditions}

The mining rate constant $k_{m}^{M b}$ for Canada, was found to be equal to 10 by fitting the model to the Canadian data. The same value was assumed for all other countries where production has not yet commenced. An approximate maximum production of each mine for Canadian production was assumed to be $0.01 \mathrm{~Gb} / \mathrm{y}$ 
$(\sim 0.03 \mathrm{Mb} / \mathrm{d})$. During the period when Suncor was the only mine in Canada (1967-1978) production was more like $0.02 \mathrm{~Gb} / \mathrm{y}(\sim 0.05 \mathrm{Mb} / \mathrm{d})$, but because of the ceiling function, after 1 year the model produces 2 mines, which remain for approximately 10 years, so, the maximum production for Canadian mines was set at $0.01 \mathrm{~Gb} / \mathrm{y}(\sim 0.03 \mathrm{Mb} / \mathrm{d})$. The mines used in the Canadian oil sands industry are amongst the biggest mines in the world, for this reason a long mine life was assumed essential and was set at 80 years. The mining rate constant $k_{m}^{M b}$ for Canada, was found to be equal to 10 by fitting the model to the Canadian data. Figure 4 shows the fit between the model and the data for the Canadian tar sands mining $\left(R^{2}=0.96\right.$ for pessimistic and best guess cases, and 0.93 for optimistic case). The same rate constant $k_{m}^{M b}=10$ was assumed for all other countries where production has not yet commenced. The maximum production of a mine and the life of the mine was determined directly from the ultimately recoverable reserves of the basin, as indicated in Equations 13 and 14.

$$
\begin{gathered}
M_{p}^{M b}=\left\{\begin{array}{l}
0.01 \mathrm{~Gb} / \mathrm{y}(27 \mathrm{~kb} / \mathrm{d}), \text { if } U R R^{M b} \geq 10 \\
0.005 \mathrm{~Gb} / \mathrm{y}(14 \mathrm{~kb} / \mathrm{d}), \text { if } 1<U R R^{M b}<10 \\
0.001 \mathrm{~Gb} / \mathrm{y}(3 \mathrm{~kb} / \mathrm{d}), \text { if } U R R^{M b} \leq 1
\end{array}\right. \\
M_{L}^{M b}=\left\{\begin{array}{l}
80 \mathrm{y}, \text { if } U R R^{M b} \geq 10 \\
60 \mathrm{y}, \text { if } 1<U R R^{M b}<10 \\
40 \mathrm{y}, \text { if } U R R^{M b} \leq 1
\end{array}\right.
\end{gathered}
$$

In the US Green River deposit production will be limited due to a lack of water availability. The pessimistic case limits production to $0.3 \mathrm{~Gb} / \mathrm{y}(0.7 \mathrm{Mb} / \mathrm{d})$, the best guess case to $2 \mathrm{~Gb} / \mathrm{y}(5.7 \mathrm{Mb} / \mathrm{d})$ and the optimistic case is restricted to 4 $\mathrm{Gb} / \mathrm{y}(10.7 \mathrm{Mb} / \mathrm{d})$. For more information on how these numbers were determined see Appendix. The constants for the mining model for all basins are shown in Tables 6 and 7.

Tables 6 and 7 hereabouts

\section{Results and Discussion}

The in-situ model was used to model in-situ natural bitumen production and extra heavy oil production. The mining model was used to predict production from mined natural bitumen and shale oil production. Currently shale oil is extracted via mining and retorting techniques; in the future, production particularly in the Green River and Devonian basins could be from in-situ techniques, however extraction methods are still in the research and development phase. Due to the lack 
of in-situ techniques currently available, it is assumed that shale oil production is via mining methods only.

Unconventional oil production for the three different scenarios are shown in Figure 5. The unconventional oil has been split into the different types of unconventional oil production, namely natural bitumen, extra heavy oil and shale oil. Unconventional oil production is anticipated to peak between $18 \mathrm{~Gb} / \mathrm{y}(49 \mathrm{Mb} / \mathrm{d}$ ) in 2076 and $32 \mathrm{~Gb} / \mathrm{y}$ ( $88 \mathrm{Mb} / \mathrm{d}$ ) in 2084, with the best guess scenario of $22 \mathrm{~Gb} / \mathrm{y}$ $(60 \mathrm{Mb} / \mathrm{d})$ in 2077 .general shale oil has the biggest potential production, with shale oil peaking at $10 \mathrm{~Gb} / \mathrm{y}(27 \mathrm{Mb} / \mathrm{d})$ in 2108 for the pessimistic case, $12.9 \mathrm{~Gb} / \mathrm{y}$ ( $35.3 \mathrm{Mb} / \mathrm{d})$ in 2105 for the best guess scenario and $19 \mathrm{~Gb} / \mathrm{y}(52 \mathrm{Mb} / \mathrm{d})$ in 2123 for the optimistic case. Although oil shale has the greatest potential, it also has the greatest uncertainty surrounding its extraction methods and economic viability. Extraction methods in the past have been via mining; however Shell is developing an in-situ method of recovery (Shell, 2007). In terms of economics, Shell have argued that shale oil is potentially economical at $\sim \$ 25$ a barrel (Fletcher, 2005b), however Australia oil shale production ceased in 2004 stating that production was uneconomic Francu et al. (2007).

Figure 6 shows the unconventional oil production by countries for the three different scenarios. Unconventional oil is found in three main countries: natural bitumen in Canada, extra heavy oil in Venezuela, and shale oil in USA. Figure 6 shows that these three countries are the biggest producers of unconventional oil. Along with these nations, the Former Soviet Union countries will also have considerable unconventional oil production with all scenarios indicating FSU unconventional oil production to be greater than $8 \mathrm{Mb} / \mathrm{d}$ by 2100 .

Literature and our estimate for Canadian natural bitumen is shown in Figure 7. The literature scenarios and our estimates are shown up to 2030, with our estimates ranging from 4.5 to $5.8 \mathrm{Mb} / \mathrm{d}$ in 2030. In 2030 both Greene et al. (2006) and the U.S. Department of Energy (2008) high price scenario are significantly higher than our forecasts, with Greene et al. (2006) estimating $12.6 \mathrm{Mb} / \mathrm{d}$ and U.S. Department of Energy (2008) high price scenario indicating 8.7 Mb/d. The U.S. Department of Energy (2008) low price and low growth scenarios are both considerably below our estimate with projections of 1.4 and $1.7 \mathrm{Mb} / \mathrm{d}$ respectfully. The bulk of literature projections U.S. Department of Energy (2008) reference and high growth cases, Zittel and Schindler (2007), Caruso (2005), along with all three of Söderbergh (2005) have a range of $3.4 \mathrm{Mb} / \mathrm{d}$ to $6.9 \mathrm{Mb} / \mathrm{d}$ in 2030, which is close to our projection of 4.5 to $5.8 \mathrm{Mb} / \mathrm{d}$. Our projections of Canadian natural bitumen agree with the bulk of the literature estimates.

Literature and our estimate of Venezuelan extra heavy oil production is shown 
in Figure 8. Our projections up to 2030 indicate that extra heavy oil production will yield $\sim 1 \mathrm{Mb} / \mathrm{d}$ in 2012, and 3.7 to $4.0 \mathrm{Mb} / \mathrm{d}$ in 2030. Shorter term projections from Moritis (2005) and Smith (2007) indicate production in 2012 will be 1.2 to $1.9 \mathrm{Mb} / \mathrm{d}$ notably higher than our estimate for the time period of $1 \mathrm{Mb} / \mathrm{d}$. The U.S. Department of Energy (2008) estimates in 2030 are between 1.1 and $2.1 \mathrm{Mb} / \mathrm{d}$ which is lower than our estimate of 3.7 to $4.0 \mathrm{Mb} / \mathrm{d}$ in 2030 . However Greene et al. (2006) indicates the production will be around $6 \mathrm{Mb} / \mathrm{d}$ in 2030 considerably higher than our estimate. There is considerable range of estimates for Venezuelan extra heavy oil production, however our production estimate is within literature estimates if on the optimistic side.

Figure 9 shows literature and our projections of world unconventional oil production up to 2030. Our projection of unconventional oil reaches 10.7 to 10.9 $\mathrm{Mb} / \mathrm{d}$ in 2030. Edwards (1997) projects unconventional oil far lower than our estimates with $0.9 \mathrm{Mb} / \mathrm{d}$ in 2030. The U.S. Department of Energy (2008) high price case has production higher than our projections at $11.2 \mathrm{Mb} / \mathrm{d}$ in 2030 . However the other U.S. Department of Energy (2008) projections which range from 2.5 to $6.6 \mathrm{Mb} / \mathrm{d}$ are lower than our estimates at 2030. Koppelaar (2007) is slightly higher than our projection with 10.7 to $12.1 \mathrm{Mb} / \mathrm{d}$ in 2030. Greene et al. (2006) is significantly higher than our estimates in the future with $27.8 \mathrm{Mb} / \mathrm{d}$ in 2030 . Our total unconventional oil production projections can be thought of as on the high end of the literature estimates.

Figure 10 shows the unconventional growth rates up to 2050. The growth rates for unconventional oil in our models are between 7-11\% up to 2025, and thereafter decline slowly to $4-5 \%$ by 2050 . Greene et al. (2006); De Castro et al. (2009) indicate that very high growth rates in unconventional oil production are needed for the future. Greene et al. (2006) indicates that a growth rate of around 7-9 $\%$ is needed if non Middle-East oil production is near peak production, whereas, De Castro et al. (2009) shows that unconventional oil growth rates in excess of $10 \%$ are needed to mitigate conventional peak oil. Based only on growth rate assumptions from literature, it might be possible for unconventional oil to mitigate conventional oil declines.

Figure 11 shows combined conventional and unconventional oil production. The conventional oil production includes three projections and is from Mohr and Evans (2008). The combined total oil production in Figure 11 shows that the pessimistic oil production scenario peaks in 2010 at $31 \mathrm{~Gb} / \mathrm{y}(84 \mathrm{Mb} / \mathrm{d})$. The total oil production best guess scenario is projected to peak in 2014 at $32 \mathrm{~Gb} / \mathrm{y}$ $(87 \mathrm{Mb} / \mathrm{d})$. In the optimistic scenario conventional oil peaks in 2025 and total oil production predicted to peak around 2050 (2052 at $39 \mathrm{~Gb} / \mathrm{y}$ or $106 \mathrm{Mb} / \mathrm{d}$ ). 
Although the optimistic scenario peaks in the long term future, demand for oil in 2030 is projected to be $40 \mathrm{~Gb} / \mathrm{y}(109 \mathrm{Mb} / \mathrm{d})^{2} \mathrm{U} . \mathrm{S}$. Department of Energy (2008), whereas even in the Optimistic scenario production is only $36 \mathrm{~Gb} / \mathrm{d}(99 \mathrm{Mb} / \mathrm{d})$, so even with optimistic scenarios there will be insufficient oil supplies by 2030 . Combining conventional and unconventional oil production indicates that only in a very optimistic scenario can oil production peak after the next 5 years.

The scenarios presented in this article ought to be considered optimistic given the lack of economic constraints and EROEI constraints (e.g. shale oil extraction is currently expensive and energy intensive). Despite the optimistic nature of the assumptions in these scenarios, total oil production is forecasted to decline within 5 years for both the pessimistic and best guess scenarios. Only in the optimistic scenario does total oil production not peak in the near future. The analysis of unconventional oil indicates that at the absolute best it can only delay the peaking of world oil production by about 25 years.

Figures 5-11 hereabouts

\section{Conclusion}

A model has been developed to predict unconventional oil production for the next 200 years. Three scenarios (Pessimistic, Best Guess, and Optimistic) where chosen with URR's ranging from $2000 \mathrm{~Gb}$ to $3750 \mathrm{~Gb}$. The developed model projected unconventional oil production oil production to peak between $18 \mathrm{~Gb} / \mathrm{y}$ (49 $\mathrm{Mb} / \mathrm{d}$ ) in 2076 to $32 \mathrm{~Gb} / \mathrm{y}(88 \mathrm{Mb} / \mathrm{d})$ in 2084. The Best Guess scenario assumed a URR of $2500 \mathrm{~Gb}$ and peaked in 2077 at $22 \mathrm{~Gb} / \mathrm{y}(60 \mathrm{Mb} / \mathrm{d})$. When combined with literature projections of conventional oil production, total oil production in both the pessimistic and best guess scenarios peaked within the next 5 years, with only the optimistic scenario having unconventional oil partially mitigating conventional oil peaking. The optimistic scenario of total oil production peaks around 2050.

\section{Acknowledgments}

Steve Mohr wishes to thank the Centre for Sustainable Resource Processing for funding.

\footnotetext{
${ }^{2} 4 \mathrm{Mb} / \mathrm{d}$ of Coal to Liquid, Gas to Liquid and Biofuels have been removed from the U.S. Department of Energy (2008) projection to make the definitions of oil as similar as possible
} 


\section{Nomenclature}

\section{Functions}

$C^{I b o}(t)$ The Cumulative production of oil in the $b$-th basin $(\mathrm{Gb})$

$C_{l}^{I b o}(t)$ The Cumulative production for the $l^{\text {th }}$ SAGD/CSS plant in the $b$-th basin as a function of time $(\mathrm{Gb})$

$C_{l i}^{I b o}(t)$ The Cumulative production of oil for the $i$-th well in the $l$-th SAGD/CSS plant, in the $b$-th basin $(\mathrm{Gb})$

$C_{l i}^{I b w}(t)$ The Cumulative production of water for the $i$-th well in the $l$-th SAGD/CSS plant, in the $b$-th basin $(\mathrm{Gb})$

$C_{l}^{M b}(t)$ The Cumulative production of oil, from the $l$-th mine in the $b$-th basin (Gb)

$f_{l i}^{I b o}(t)$ The fraction of oil, in the $i$-th well of the $l$-th SAGD/CSS plant in the $b$-th basin (-)

$n_{S}^{I b}(t)$ The number of SAGD/CSS plants in the $b$-th basin as a function of time (-)

$n_{w l}^{I b}(t)$ The number of well pairs in operation for the $l^{\text {th }}$ SAGD/CSS plant in the $b$-th basin as a function of time (-)

$n^{M b}(t)$ The number of mines on-line in the $b$-th basin as a function of time (-)

$P^{I b}(t)$ The production from the $b$-th basin from the in-situ model

$P_{l i}^{I b}(t)$ The production of oil from the $i$-th well in the $l$-th SAGD/CSS plant in the $b$-th basin $(\mathrm{Gb} / \mathrm{y})$

$P^{M b}(t)$ The mining production from the $b$-th basin

$P_{l}^{M b}(t)$ The production from the $l$-th mine in the $b$-th basin

$R^{2} \quad$ The coefficient of determination (-)

\section{Variables}

$K_{l i}^{I b} \quad$ Constant linking production to pressure in the $i$-th well of the $l$-the SAGD/CSS plant in the $b$-th basin $(\mathrm{Gb} / \mathrm{Pa})$ 
$k_{S}^{I b} \quad$ The proportionality constant for the number of SAGD/CSS plants in the $b$-th basin (-)

$k_{w l}^{I b} \quad$ The proportionality constant for the number of well pairs built in the $l$-th SAGD/CSS plant, in the $b$-th basin (-)

$k^{M b} \quad$ The proportionality constant for the number of mines in the $b$-th basin (-)

$k^{M} \quad$ The proportionality constant for the number of mines (-)

$k_{S} \quad$ The proportionality constant for the number of SAGD/CSS plants (-)

$k_{w} \quad$ The proportionality constant for the number of well pairs (-)

$M_{l L}^{M b}$ The mine life of the $l$-th mine in the $b$-th basin (y)

$M_{L}^{M b}$ The mine life of the mines in the $b$-th basin $(\mathrm{Gb} / \mathrm{y})$

$M_{l p}^{M b}$ The maximum production of the $l$-th mine in the $b$-th basin $(\mathrm{Gb} / \mathrm{y})$

$M_{p}^{M b}$ The maximum production of the mines in the $b$-th basin $(\mathrm{Gb} / \mathrm{y})$

$N_{S}^{I b} \quad$ The total number of SAGD/CSS plants in the $b$-th basin (-)

$N_{w l}^{I b} \quad$ The total number of SAGD well pairs in operation in the $l^{\text {th }}$ SAGD/CSS plant in the $b$-th basin (-)

$N^{M b}$ The total number of mines in the $b$-th basin (-)

$p_{0} \quad$ The initial production of the wells in the SAGD/CSS plants (Gb/y)

$p_{M} \quad$ The maximum production from an in-situ plant

$P r_{l i}^{I b} \quad$ The pressure of the $i$-th well in the $l$-th SAGD/CSS plant in the $b$-th basin (Pa)

$t \quad$ time $(\mathrm{y})$

$t_{l}^{I b} \quad$ The year the $l$-th SAGD/CSS plant in the $b$-th basin comes on-line (y)

$t_{l i}^{I b} \quad$ The year the $i$-th well in the $l$-th SAGD/CSS plant in the $b$-th basin comes on-line (y)

$t^{M b} \quad$ The year the $b$-th mining basin comes on-line (y) 
$U R R^{I b}$ The in-situ Ultimately Recoverable Resources in the $b$-th basin $(\mathrm{Gb})$

$U R R_{l}^{I b}$ The in-situ Ultimately Recoverable Resources for the $l^{\text {th }}$ SAGD/CSS plant in the $b$-th basin, $(\mathrm{Gb})$

$U R R_{l}^{I}$ The in-situ Ultimately Recoverable Resources for the $l^{\text {th }}$ SAGD/CSS plants, $(\mathrm{Gb})$

$U R R_{l i}^{I b}$ The in-situ Ultimately Recoverable Resources of the $i$-th well in the $l$-th $\mathrm{SAGD} / \mathrm{CSS}$ plant in the $b$-th basin $(\mathrm{Gb})$

$U R R^{M b}$ The mining Ultimately Recoverable Resources in the $b$-th basin $(\mathrm{Gb})$ 


\section{References}

Adewusi V. A., 1992. Aspects of tar sands development in Nigeria. Energy Sources, 14(3), 305-315.

Akin S., 2005. Mathematical modeling of steam-assisted gravity drainage. SPE Reservoir Evaluation \& Engineering, 8(5), 372-376.

Aleklett K., 2004. International Energy Agency accepts Peak Oil. ASPO website, $\langle$ http://www.peakoil.net/uhdsg/weo2004/TheUppsalaCode.html〉 (11/27/07).

Ali S. M. F., 2003. Heavy Oil - evermore mobile. Journal of Petroleum Science and Engineering, 37, 5-9.

Bakhtiari, A. M. S., 2004. World oil production capacity model suggests output peak by 2006-07. Oil and Gas Journal, 102(16), 18-20.

Bartis J. T., LaTourrette T., Dixon L., Peterson D. J., Cecchine G., 2005. Oil Shale Development in the United States, Prospects and Policy Issues. Rand Corporation website $\langle$ http://www.rand.org/pubs/monographs/2005/RAND_MG414.pdf $\rangle$ (7/20/08)

Bekri O., 1992. Possibilities for Oil Shale Development in Morocco. Energeia 3(5), 1-2.

Broquet P., Mascle G., Monnier M., 1984. La formation Tripoli du basin de Caltanissetta. Revue de Geologie Dynamique et de Geographie Physique, 25, 8798.

Cane R. F., 1979. The Oil Shales of Australia and Their Industrial History. Twelfth Oil Shale Symposium Proceedings, 18-20th April 1979.

Caruso G., 2005. When Will World Oil Production Peak? 10th Annual Asia Oil and Gas Conference, Kuala Lumpur, Malaysia, June 13, EIA website $\langle$ www.eia.doe.gov/neic/speeches/Caruso061305.pdf $\rangle$ (8/7/08)

De Castro C., Miguel L. J., Mediavilla M., 2009. The role of non conventional oil in the attenuation of peak oil. Energy Policy, 37, 1825-1833.

Deffeyes, K. S., 2002. World's oil production peak reckoned in near future. Oil and Gas Journal, 100(46), 46-48. 
Derkey P. D., Abercrombie F. N., Vuke S. M., Daniel J. A., 1985. Geology and oil shale resources of the heath formation Fergus County Montana. Memoirs of Montana Bureau of Mines and Geology, 57.

Dyni J. R., 1988. Review of the geology and shale-oil resources of the Tripolitic oil-shale deposits of Sicily, Italy. USGS, open report 88-270.

Dyni J. R., 2003. Geology and Resources of some world oil-shale deposits. Oil Shale 20(3), 193-252.

Edwards, J. D., 1997. Crude oil and alternative energy production forecasts for the twenty-first century. AAPG Bulletin 81, 1292-1305.

Fletcher S., 2005. N. American unconventional oil a potential energy bridge. Oil and Gas Journal, 103(14), 22-26.

Fletcher S., 2005. Industry, US government take new look at oil shale. Oil and Gas Journal, 103(15), 26-28.

Francu J., Harvie B., Laenen B., Siirde A., Veiderma M., A study on the EU oil shale industry - viewed in the light of the Estonian experience. (IP/A/ITRE/FWC/2005-60/SC4)

www.europarl.europa.eu/meetdocs/2004_2009/documents/dv/ip_a_itre_st_2006_ip_a_itre_st_2006_10.p $(29 / 8 / 09)$

Greene D. L., Hopson J. L., and Li J., 2006. Have we run out of oil yet? Oil peaking analysis from an optimist's perspective. Energy Policy, 34, 515-531.

Griffiths M., Taylor A., Woynillowicz D., 2006. Troubled Waters, Troubled Trends, Technology and Policy Options to Reduce Water Use in Oil and Oil Sands Development in Alberta $1^{\text {st }}$ ed. The Pembina Institute website, $\langle$ http://pubs.pembina.org/reports/TroubledW_Full.pdf $\rangle$ (8/6/08).

Hobbs G. W., 1995. Energy minerals -2 Oil, gas, coal, uranium, tar sands resources trends on rise. Oil and Gas Journal, 93(36), 104-8.

Japan Canada Oil Sands Limited, 2007. Hangingstone demonstration project 2006, Thermal In-situ Scheme Progress Report, Approval No. 8788D. Energy Resources Conservation Board, 〈http://www.ercb.ca/docs/products/osprogressreports/2007/2007AthabascaJAC OSHangingstoneSAGD8788.pdf $\rangle$ (8/6/08) 
James K. H., 2000. The Venezuelan hydrocarbon habitat, part 1: Tectonics, structure, Palaeography and source rocks. Journal of Petroleum Geology, 23(1), 553.

Jeans P. J. F., and Meerbeke G. L. E., N., D. Geological evolution and hydrocarbon habitat of the Majunga Basin and Karroo Corridor, Madagascar. Peter Jeans website, 〈http://www.pj-exploration.com/madagascar.htm 〉 (10/23/07)

Koppelaar, R. H. E. M., 2005. World Oil Production \& Peaking Outlook. The Oil Depletion Analysis Centre website, 〈www.odacinfo.org/assessments/documents/ponlreport.pdf $\rangle(12 / 10 / 07)$

Liu R., Wang H., Yang N., Cong L., Zheng D., Mu F., 2007. The Resources of China's Oil Shale and the Prospect of its Exploitation and Utilization. 27th Oil Shale Symposium, 15-19th October 2007, Colorado.

Long Lake website, 2009. 〈http://www.longlake.ca/〉 (4/22/09)

Madagascar Oil website, 2007. 〈http://www.madagascaroil.com〉(10/23/07)

Meyer R. F., 1998. World heavy crude oil resources. Proceedings of the 15 th World Petroleum Congress, 459-471.

Meyer R. F., Freeman P. A., 2006. Siberian Platform: Geology and Natural Bitumen Resources. USGS open file, 2006-1316.

Meyerhoff A. A. and Meyer R. F., 1987. Geology of heavy crude oil and natural bitumen in the USSR, Mongolia and China. AAPG studies in Geology, 25, 31101.

Ministry of Solid Minerals Development, 2006. Technical Overview: Nigeria's bitumen belt and development potential. Ministry of Solid Minerals Development website, 〈http://msmd.gov.ng/privatisation/docs/Bitumen\%20Overview.pdf $\rangle$ $(10 / 23 / 07)$

Mohr, S. H. and G. M. Evans., 2007. Mathematical model forecasts year conventional oil will peak. Oil and Gas Journal, 105(17), 45-50.

Mohr, S. H., and Evans G. M., 2008. Peak Oil: Testing Hubbert's curve via theoretical modeling. Natural Resources Research, 17(1), 1-11. 
Mohr, S. H. and G. M. Evans., 2009. Forecasting coal production until 2100, 88(11), 2059-2067.

Moritis G., 2005, Venezuela plans Orinoco expansion. Oil and Gas Journal, 103(43), 54-56.

Moritis G., 2006, Alberta bitumen output to triple in next 10 years. Oil and Gas Journal, 104(36), 39-47.

N.C.E.P., 2004. NCEP Staff Background Paper - Unconventional Oil. National Commission on Energy Policy website. $\quad$ http://www.energycommission.org/files/finalReport/I.3.a\%20\%20Unconventional\%20Oil.pdf $\rangle(12 / 17 / 07)$

National Energy Board, 2006. Canada's Oil Sands Opportunities and Challenges to 2015: An update. National Energy Board Report.

Paez R., Luzardo L., Guitian J., 2000. Current and future upgrading options for the Orinoco heavy crude oils. Proceedings of the Sixteenth World Petroleum Congress, $78-87$

Rusk, D C., Bertagne R. C., Flores G., Stowe M., Butler S., Trommestad K., Gilleran P., N. D. Petroleum geology and geophysics of the Mozambique Channel. Marex Petroleum website, $\langle$ http://www.petromarex.com/projects/moz/Mozambique_Brochure.pdf $\rangle$ $(11 / 17 / 07)$

Russell P. L., 1990. Oil Shales of the world their origin occurrence and exploitation, Pergamon Press.

Sener M., Senguler L., Kok M. V., 1995. Geological considerations for the economic evaluation of oil shale deposits in Turkey. Fuel, 74(7), 999-1003.

Shell, 2007. Protecting the groundwater. Shell Mahogany Research Project Brochure, Shell website, 〈http://www.shell.com/static/usen/downloads/shell_for_businesses/exploration_production/fwt_fact_sheet_final.pdf $\rangle$ $(9 / 17 / 08)$

Smith L. K., Unconventional Hydrocarbons: A global overview. IHS website, http://energy.ihs.com/NR/rdonlyres/D9676566-6A26-4262-93E67DA3FFEF70DE/0/GlobalUnconventionals.pdf (12/17/2007) 
Söderbergh, B. Canada's Oil Sands Resources and Its Future Impact on Global Oil Supply. Masters Thesis, Uppsala University, Sweden.

Söderbergh, B., Robelius F., and Aleklett K., 2007. A crash programme scenario for the Canadian oil sands industry. Energy Policy, 35(3), 1931-1947.

Stringham G., 2006. Canadian Natural Gas Outlook. Canadian Centre for Policy Alternatives presentation October 2006, Fort Saskatchewan, Canada.

U.S. Department of Energy, 2006. National Strategic Unconventional Resources Model. U.S. Department of Energy website, 〈www.fossil.energy.gov/programs/reserves/npr/NSURM_Documentation.pdf $\rangle$ $(10 / 23 / 07)$.

U.S. Department of Energy, 2008. International Energy Outlook 2008. U.S. Department of Energy website, 〈http://www.eia.doe.gov/oiaf/ieo/pdf/0484(2008).pdf〉 (8/11/08)

U.S. Department of the Interior, Bureau of Reclamation Upper Colorado Region, 2005. Quality of water Colorado River Basin, Progress Report No. 22. U.S. Department of the Interior website, $\langle$ http://www.usbr.gov/uc/progact/salinity/pdfs/PR22.pdf $\rangle$ (8/6/08).

U.S. Geological Survey, 2006. Natural Bitumen Resources of the United States. USGS fact sheet 2006-3133, U.S. Geological Survey website < http://pubs.usgs.gov/fs/2006/3133/pdf/FS2006-3133_508.pdf $\rangle$ (12/17/07).

Wells, P. R. A., 2005a. Oil supply challenges - 1: The non-OPEC decline. Oil and Gas Journal, 103(7), 20-28.

Wertheim P. H., 2007. Venezuela takes operational control of Orinoco oil fields. Oil and Gas Journal, 105(17), 31-34.

Wells, P. R. A., 2005b. Oil supply challenges - 2: What can OPEC deliver?. Oil and Gas Journal, 103(9), 20-30.

White A., 2006. Surge Global Energy Chief sees big oil sands potential. Oil and gas Journal, 104(16), 32-35.

Williams B., 2003. Heavy hydrocarbons playing key role in peak-oil debate, future energy supply. Oil and Gas Journal, 101(29), 20-27. 
$\begin{aligned} & \text { World Energy Council, 2007. } \\ & \text { sources, Survey of Energy Re- }\end{aligned}$ 2007. World $\langle$ http://www.worldenergy.org/publications/survey_of_energy_resources_ 2007/default.asp $\rangle(7 / 20 / 08)$

Zittel W., and Schindler J., 2007. Crude oil: The supply outlook. Report to the Energy Watch Group, EWG-Series No 3/2007. 


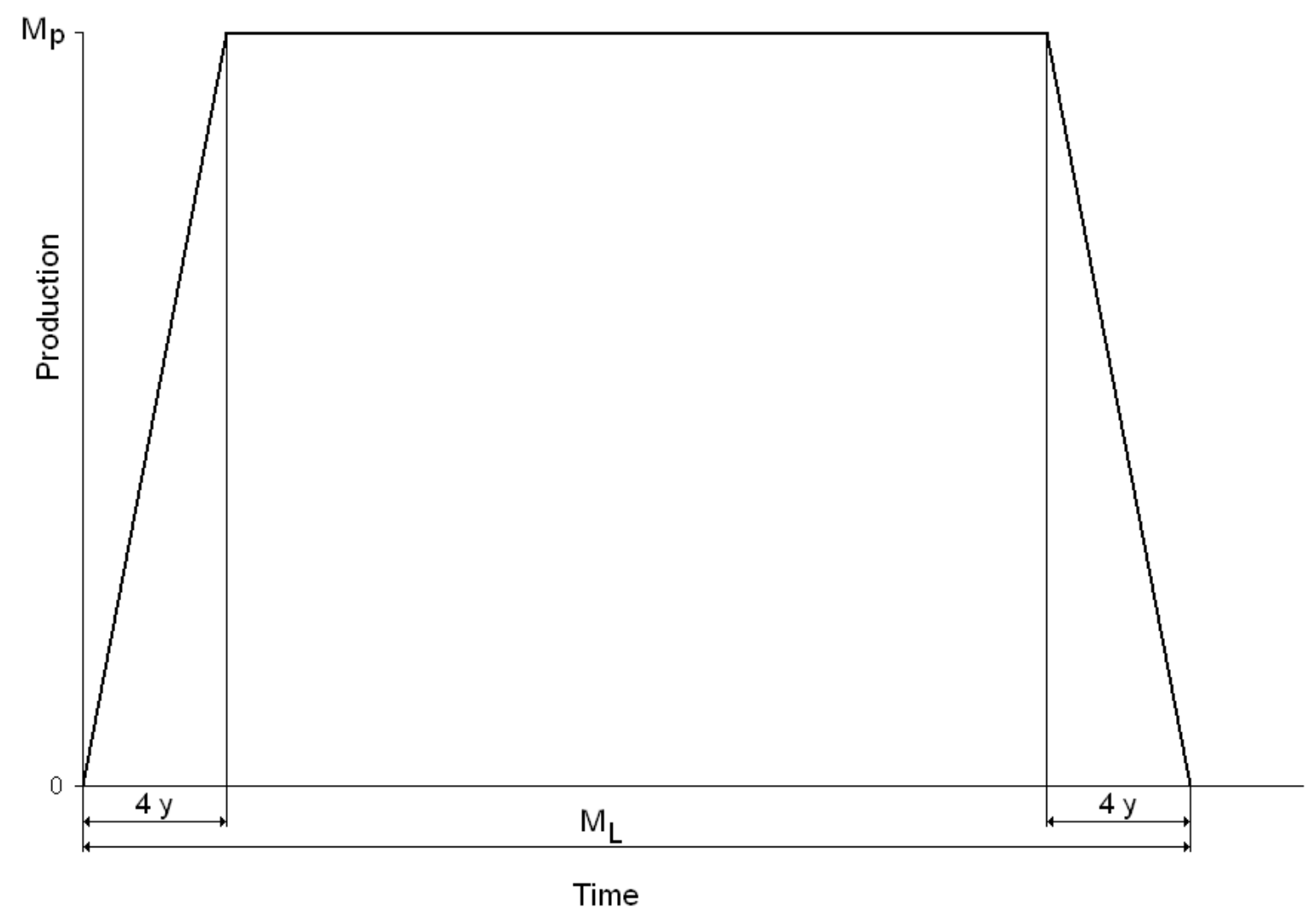

Figure 1: Schematic production profile of a mine 


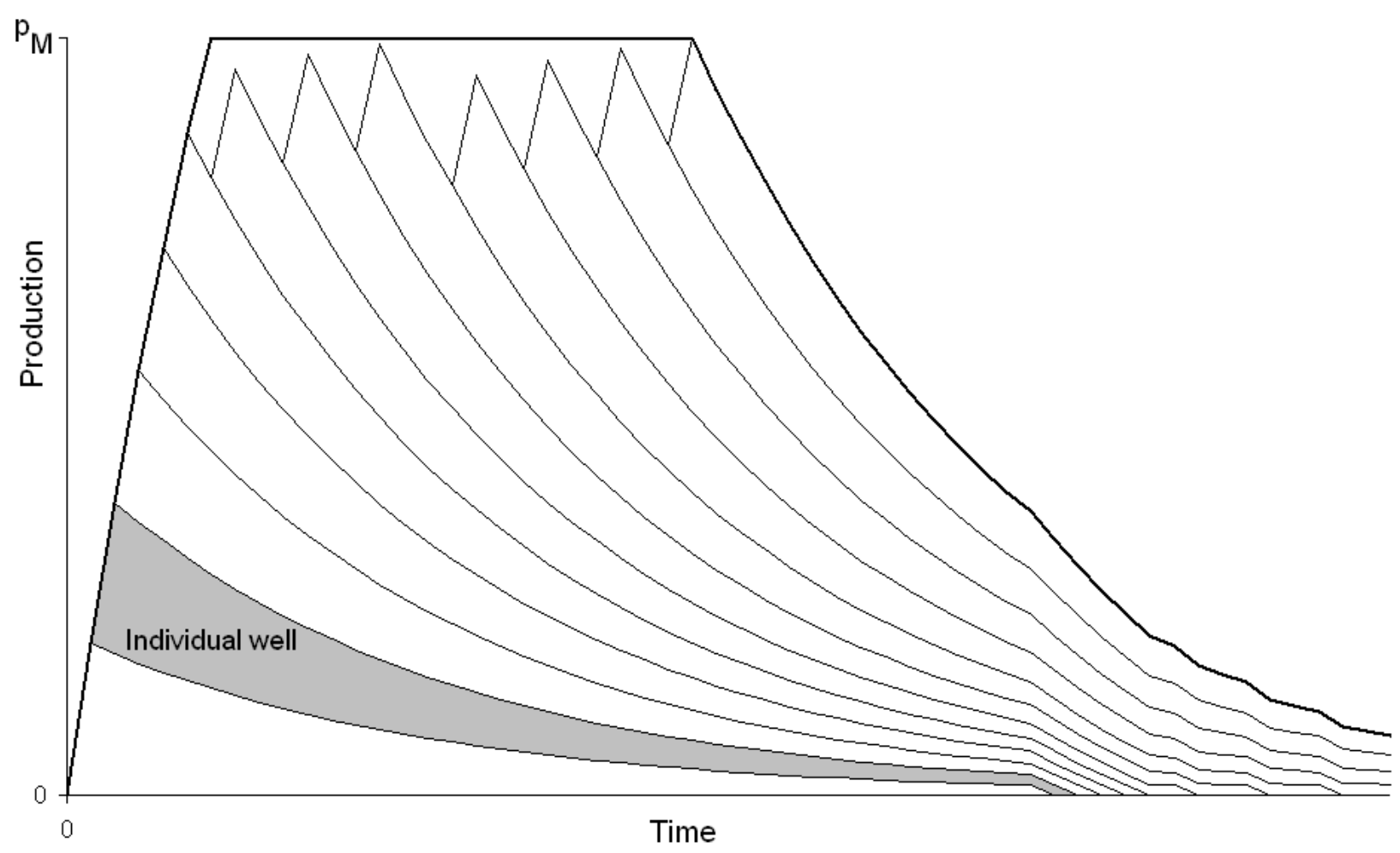

Figure 2: Schematic production profile of a SAGD/CSS plant 


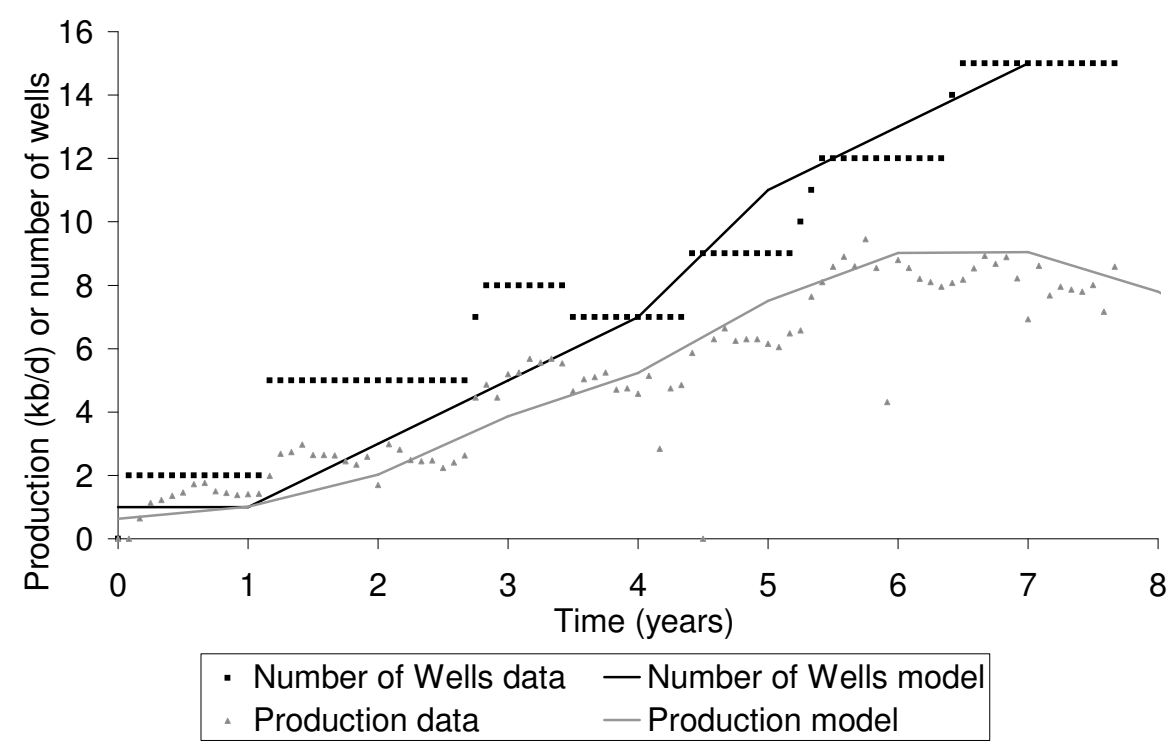

Figure 3: Reported JACOS (2007) versus predicted unconventional oil production and number of wells a SAGD Canadian bitumen plant 

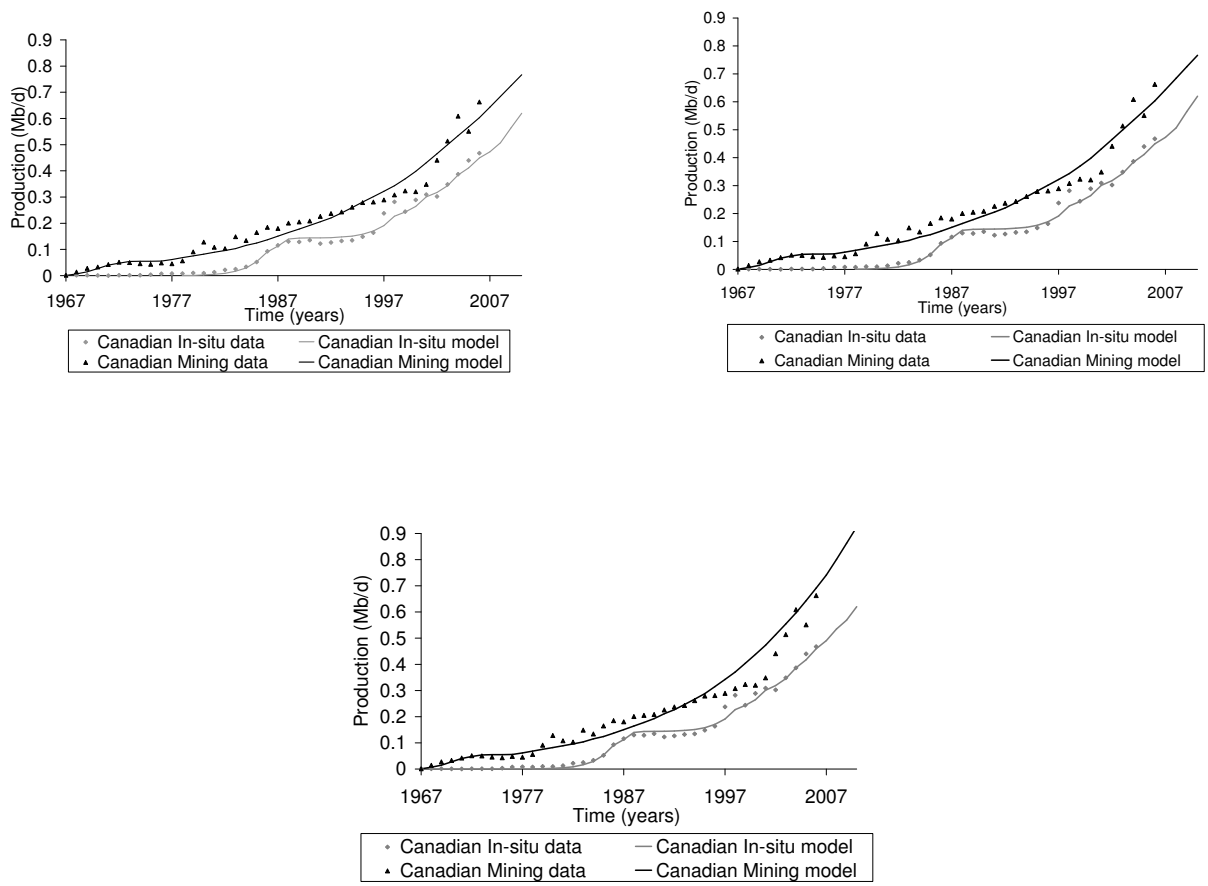

Figure 4: Unconventional oil model applied to Canadian Tar sands production, A) Pessimistic Case B) Best Guess Case C) Optimistic Case 

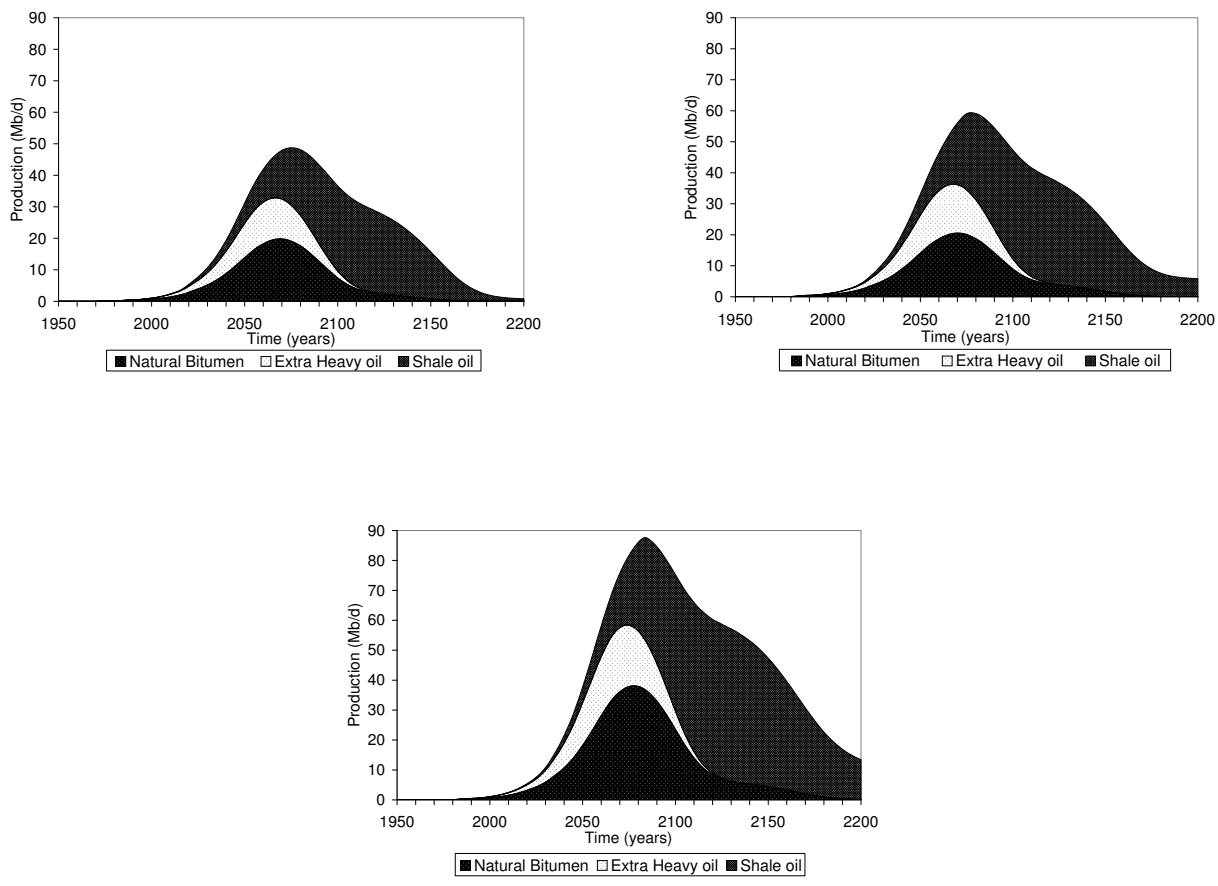

Figure 5: Unconventional oil production predictions 1950-2200 A) Pessimistic case B) Best Guess Case C) Optimistic Case 

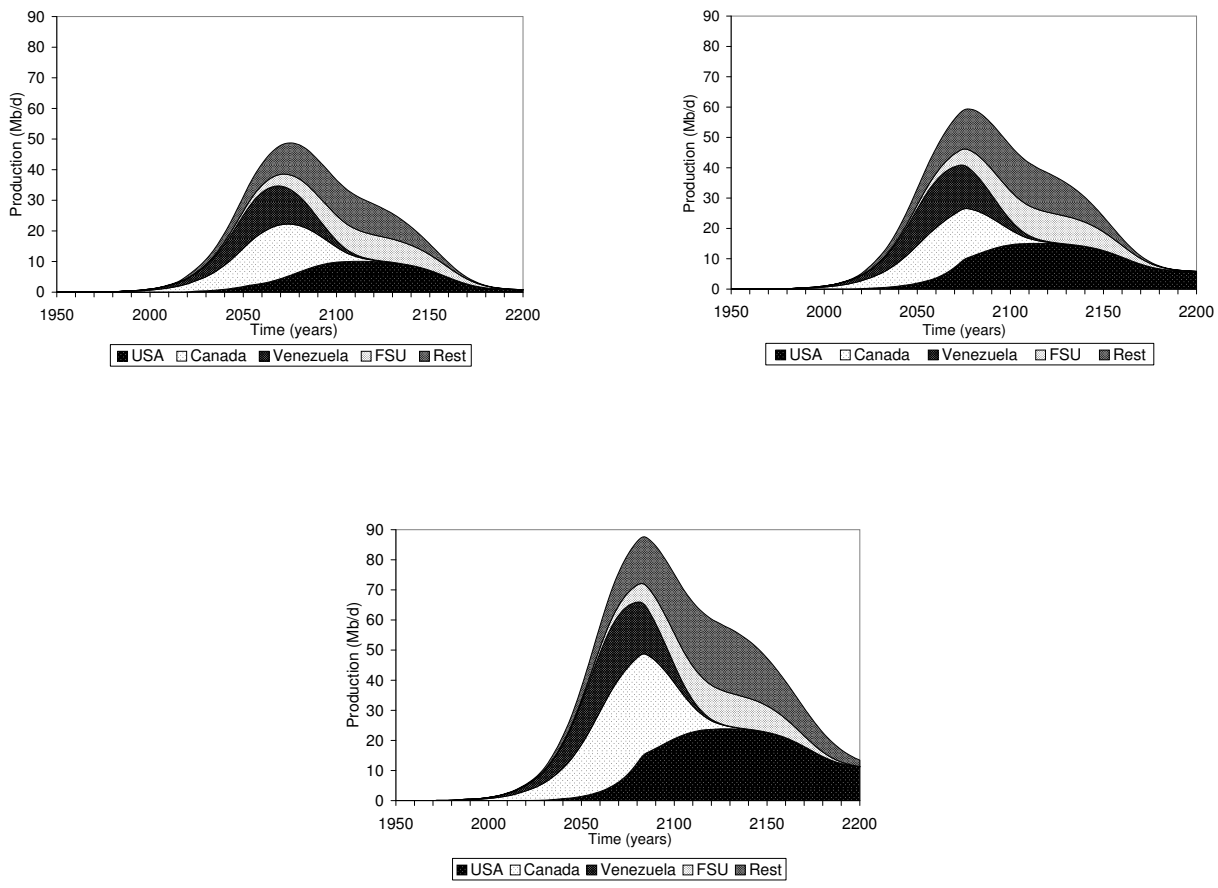

Figure 6: Unconventional oil production predictions 1950-2200 A) Pessimistic Case B) Best Guess case C) Optimistic Case 


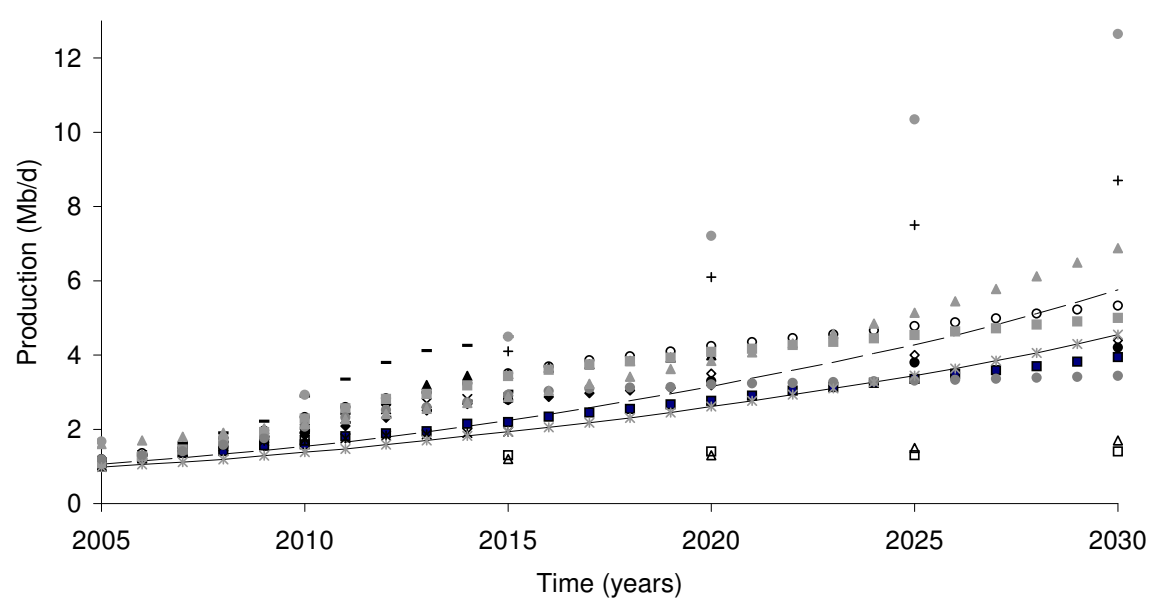

\begin{tabular}{|llll|}
\hline EWG & - Stringham A & $\Delta$ Stringham B & $\times$ Moritis \\
$*$ NEB A & - NEB B & - NEB C & $\bullet$ EIA A \\
+ EIA B & $\square$ EIA C & $\diamond$ EIA D & $\Delta$ EIA E \\
$\circ$ Soderbergh A & - Soderbergh B & - Soderbergh C & $\Delta$ Caruso \\
- Greene & $*$ Pessimistic Scenario & - BG Scenario & - -Optimistic Scenario
\end{tabular}

Figure 7: Canadian natural bitumen production predictions ${ }^{3}$ 2005-2030

${ }^{3}$ Zittel and Schindler (2007); Stringham (2006); Moritis (2006); NEB (2006); U.S. Department of Energy (2008); Söderbergh (2005); Caruso (2005); Greene et al. (2006), EIA A = EIA Reference Case, EIA B = EIA High Price Case, EIA C = EIA Low Price Case, EIA D = High Economic Growth Case, EIA E = Low Economic Growth Case 


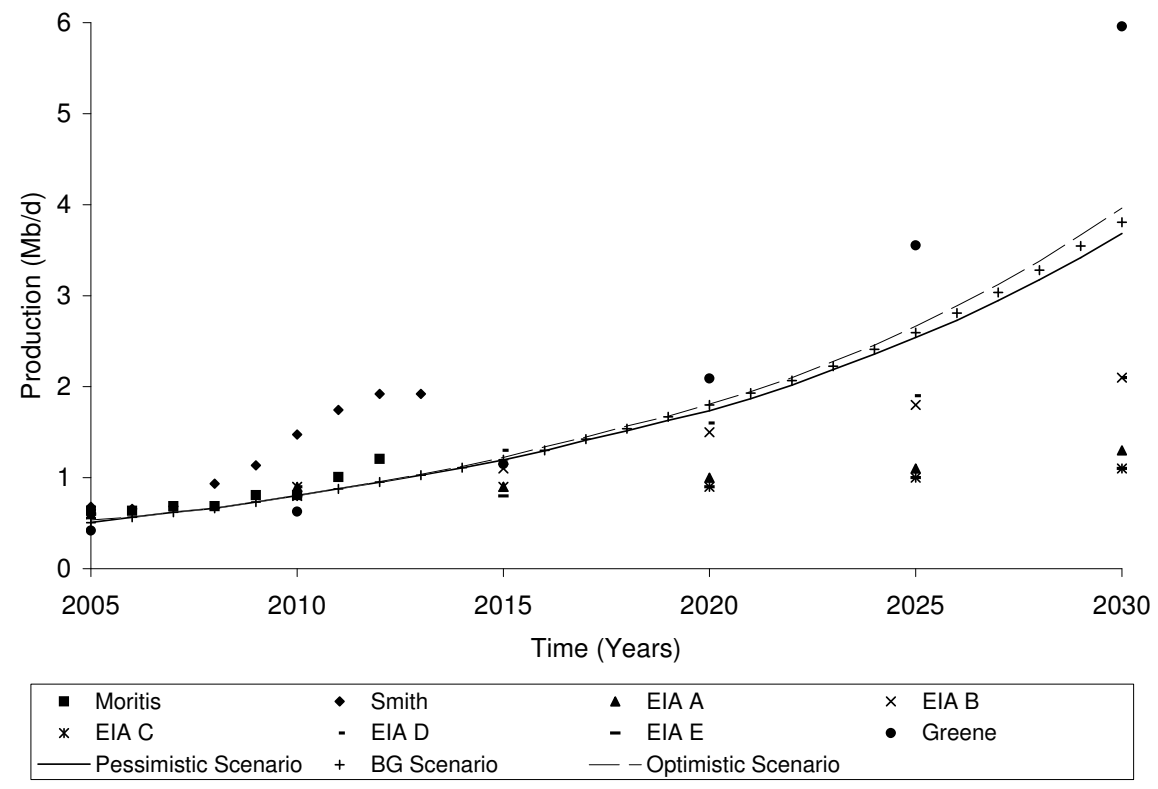

Figure 8: Venezuelan extra heavy oil production predictions ${ }^{4}$ 2005-2030

\footnotetext{
${ }^{4}$ Moritis (2005); Smith (2007); U.S. Department of Energy (2008); Greene et al. (2006), EIA $\mathrm{A}=$ EIA Reference Case, EIA B = EIA High Price Case, EIA C $=$ EIA Low Price Case, EIA D = High Economic Growth Case, EIA E = Low Economic Growth Case
} 


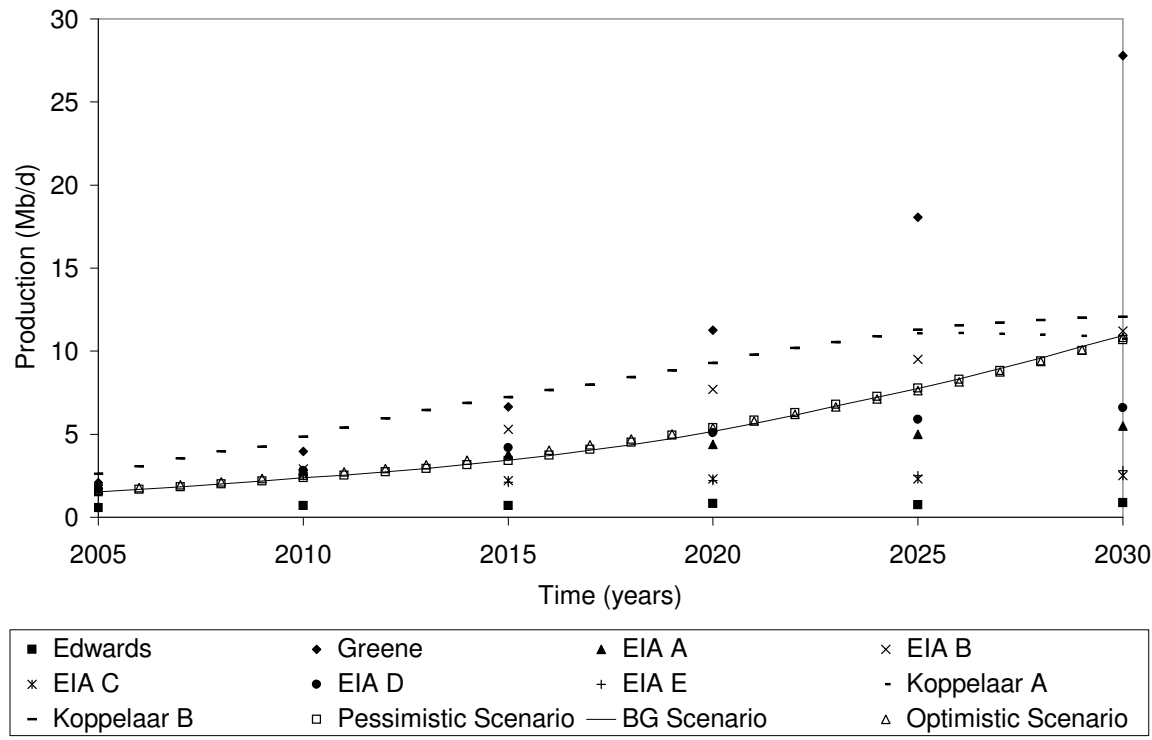

Figure 9: World unconventional oil production predictions ${ }^{5}$ 2005-2030

${ }^{5}$ Edwards (1997); Greene et al. (2006); U.S. Department of Energy (2008); Koppelaar (2007), EIA A $=$ EIA Reference Case, EIA B = EIA High Price Case, EIA C = EIA Low Price Case, EIA $\mathrm{D}=$ High Economic Growth Case, EIA E = Low Economic Growth Case 


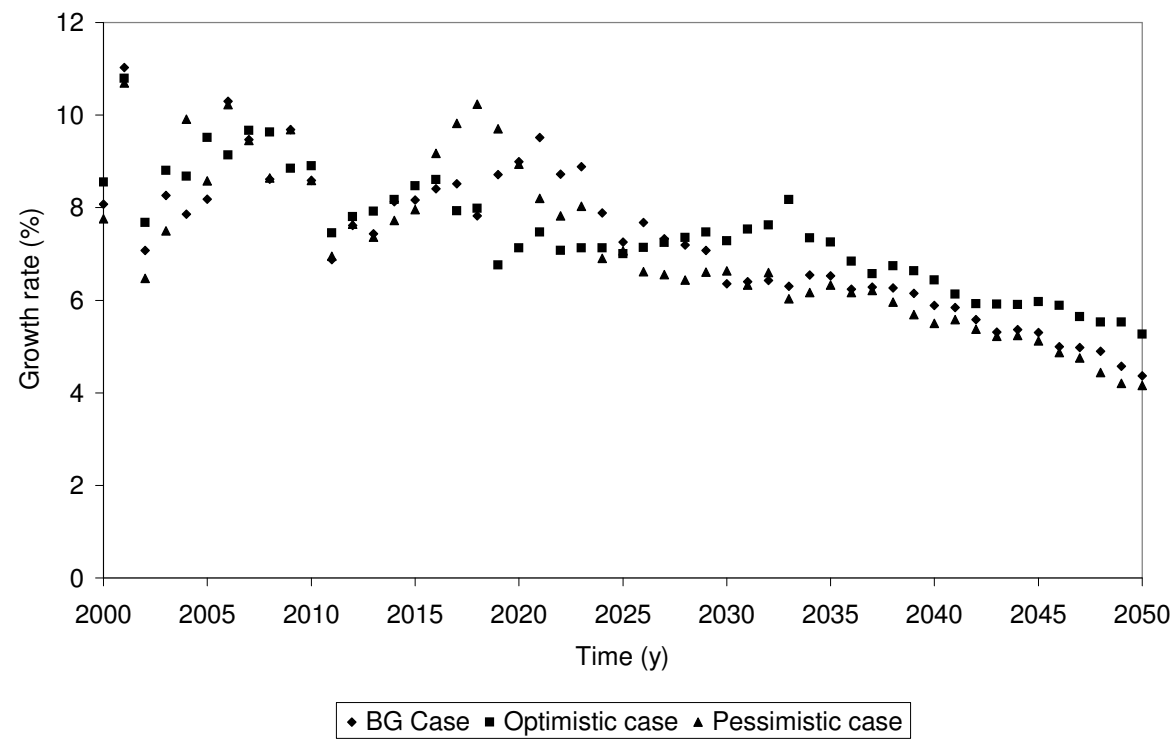

Figure 10: Unconventional oil growth rate prediction 


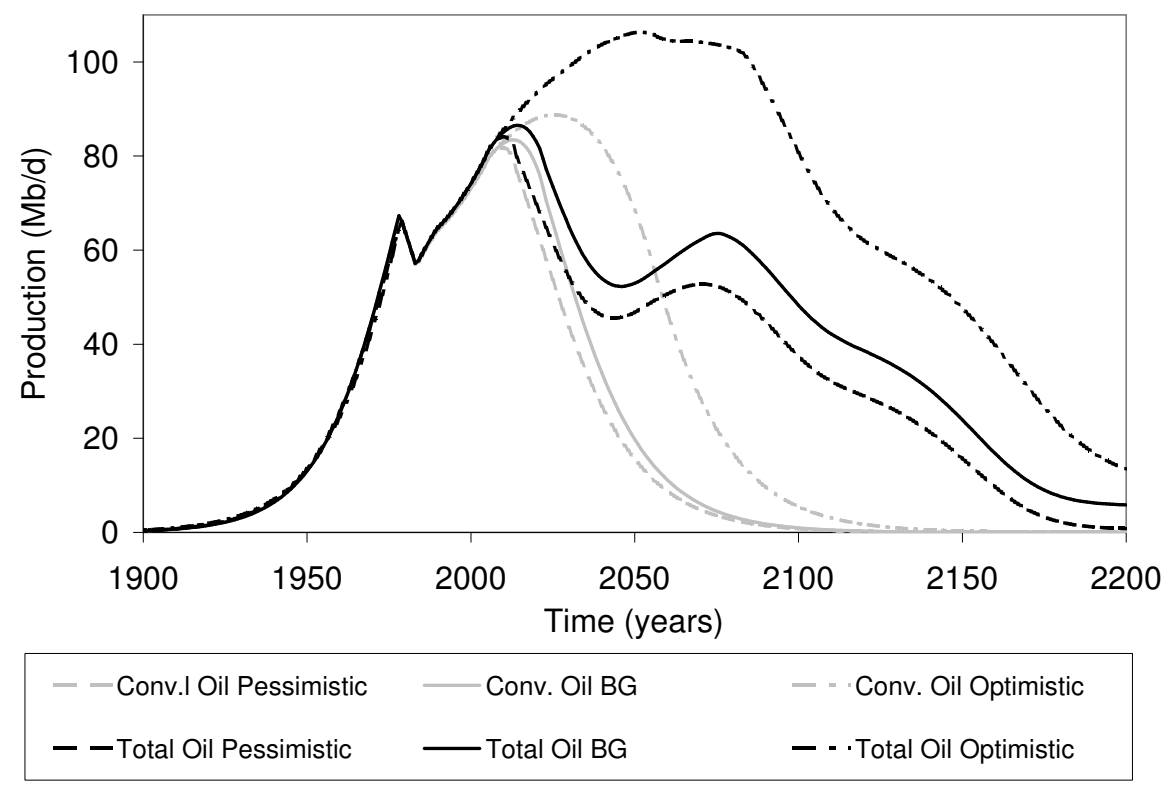

Figure 11: Combined conventional and unconventional oil production predictions ${ }^{6}$

${ }^{6}$ conventional oil projection from Mohr and Evans (2008) 
Table 1: Natural Bitumen Resource and URR Estimates

\begin{tabular}{|c|c|c|c|c|c|}
\hline \multirow{2}{*}{ Country } & \multirow{2}{*}{$\begin{array}{l}\text { Resources } \\
(\mathrm{Gb})^{\mathrm{a}}\end{array}$} & \multicolumn{3}{|c|}{ URR Gb } & \multirow{2}{*}{ Comments } \\
\hline & & $\mathrm{P}$ & BG & $\mathrm{O}$ & \\
\hline Angola & 5 & 0.7 & 0.7 & 0.7 & $\mathrm{P}, \mathrm{BG}$ and $\mathrm{O}$ assume $15 \%$ recovery \\
\hline Canada & 2400 & 350 & 350 & 700 & $\begin{array}{l}\mathrm{P} \text { and BG from WEC (2007) } \\
\text { O from White (2006) }\end{array}$ \\
\hline China & 2 & 0.2 & 0.2 & 0.2 & $\mathrm{P}, \mathrm{BG}$ and $\mathrm{O}$ assume $15 \%$ recovery \\
\hline Indonesia & 5 & 0.7 & 0.7 & 0.7 & $\mathrm{P}, \mathrm{BG}$ and $\mathrm{O}$ assume $15 \%$ recovery \\
\hline Italy & 2 & 0.3 & 0.3 & 0.3 & $\mathrm{P}, \mathrm{BG}$ and $\mathrm{O}$ assume $15 \%$ recovery \\
\hline Kazakhstan & 420 & 63 & 63 & 63 & $\mathrm{P}, \mathrm{BG}$ and $\mathrm{O}$ assume $15 \%$ recovery \\
\hline Madagascar & $2-21^{\mathrm{b}}$ & 1 & 3 & 9.8 & $\begin{array}{l}\text { P from Jeans and Meerbeke (N. D.) } \\
\text { BG from } 15 \% \text { of } 20 \mathrm{~Gb} \\
\text { O from Madagascar Oil (N. D.) }\end{array}$ \\
\hline Nigeria & $30-43^{c}$ & 4.5 & 6.5 & 6.5 & $\begin{array}{l}\mathrm{P} \text { from } 15 \% \text { of } 30 \mathrm{~Gb} \\
\mathrm{BG} \text { and } \mathrm{O} \text { from } 15 \% \text { of } 43 \mathrm{~Gb} .\end{array}$ \\
\hline Russia $^{\mathrm{d}}$ & $62-800^{\mathrm{e}}$ & 10 & 53 & 100 & $\begin{array}{l}\mathrm{P} \text { assumes } 62 \mathrm{~Gb} \text { resource and } 15 \% \text { recovery } \\
\text { BG assumes } 350 \mathrm{~Gb} \text { resource and } 15 \% \text { recovery } \\
\mathrm{O} \text { assumes } 700 \mathrm{~Gb} \text { resource and } 15 \% \text { recovery }\end{array}$ \\
\hline USA & $54-80^{\mathrm{f}}$ & 8 & 11 & 12 & $\begin{array}{l}\text { P assumes } 54 \mathrm{~Gb} \text { resources and } 15 \% \text { recovery } \\
\text { BG uses } 11 \mathrm{~Gb} \text { recovery from } \\
\text { U.S. Department of Energy (2006) } \\
\text { O assumes } 80 \mathrm{~Gb} \text { resources and } 15 \% \text { recovery }\end{array}$ \\
\hline Rest & 1 & - & - & - & insignificant \\
\hline World & $2983-3779$ & 438 & 488 & 893 & \\
\hline
\end{tabular}

${ }^{\mathrm{a}}$ WEC (2007) unless stated otherwise

${ }^{b}$ WEC (2007); Madagascar Oil (N. D.); Rusk et al. (N. D.); Jeans and Meerbeke (N. D.)

${ }^{c}$ WEC (2007); M.S.M.D. (2006); Adewusi (1992)

${ }^{d}$ bitumen has low saturation Meyer and Freeman (2006); Meyerhoff and Meyer (1987)

${ }^{\mathrm{e}}$ Resources range from Meyer and Freeman (2006)

${ }^{\mathrm{f}}$ Resources from U.S. Department of Energy (2006); U.S. Geological Survey (2006) 
Table 2: Extra Heavy Oil Resources and URR Estimates

\begin{tabular}{||l|c|c|c|c|l||}
\hline \multirow{2}{*}{ Country } & Resources & \multicolumn{3}{|c||}{ URR Gb } & \multirow{2}{*}{ Comments } \\
\cline { 3 - 5 } & $(\mathrm{Gb})$ WEC (2007) & P & BG & O & \\
\hline China & 8.9 & 1.3 & 1.3 & 1.3 & P, BG and O assume 15\% recovery \\
\hline UK & $12^{\mathrm{a}}$ & 1 & 1.5 & 2 & $\begin{array}{l}\text { P assumes 1 Gb produced (WEC, 2007) } \\
\text { BG average of P and O. } \\
\text { O assumes no oil produced }\end{array}$ \\
\hline Venezuela & $1200-2450^{\mathrm{b}}$ & 250 & 300 & 400 & $\begin{array}{l}\text { P is approx of historic estimate } \\
\text { BG is the high end of historic estimates } \\
\text { O 20\% recovery of } 2000 \text { Gb resources }\end{array}$ \\
\hline Rest & 17.6 & - & - & - & insignificant $^{\mathrm{c}}$ \\
\hline World & $1239-2489$ & 252 & 303 & 403 & \\
\hline
\end{tabular}

${ }^{\mathrm{a}}$ Lies in developed Piper field and second undeveloped basin WEC (2007).

${ }^{b}$ Williams (2003); Hobbs (1995); NCEP (2004); Moritis (2005); James (2000); Paez et al. (2000); Fletcher (2005a); WEC (2007)

${ }^{c}$ NCEP (2004); James (2000); Hobbs (1995); Paez et al. (2000); Fletcher (2005a); Wertheim (2007)

${ }^{\mathrm{d}}$ recovery factor PDVSA believes is possible Moritis (2005) 
Table 3: Shale Oil Resource and URR Estimates

\begin{tabular}{|c|c|c|c|c|c|c|}
\hline \multirow{2}{*}{ Country } & \multirow{2}{*}{$\begin{array}{l}\text { Resources } \\
(\mathrm{Gb}){ }^{\mathrm{b}}\end{array}$} & \multirow{2}{*}{$\begin{array}{c}\text { Grade }{ }^{\mathrm{a}} \\
\mathrm{L} / \mathrm{t}\end{array}$} & \multicolumn{3}{|c|}{ URR Gb } & \multirow{2}{*}{ Comments } \\
\hline & & & $\mathrm{P}$ & BG & $\mathrm{O}$ & \\
\hline Australia & $32-2030^{c}$ & & 24 & 34 & 224 & \\
\hline Toolebuc & $0-2000$ & $37-45^{\mathrm{c}}$ & 0 & 10 & 200 & $\begin{array}{l}\text { Resource limited to } 315 \mathrm{~Gb} \text { Dyni (2003) } \\
\mathrm{P} \text { assumes no prod. (grade too low) } \\
\text { BG guess, water believed issue } \\
\mathrm{O} \text { assumes } 64 \% \text { recovery of } 315 \mathrm{~Gb} \text {. }\end{array}$ \\
\hline Rest & 32 & $65-105^{d}$ & 24 & 24 & 24 & P, BG \& O from WEC (2007) \\
\hline Brazil & 82 & $70-125^{\mathrm{d}}$ & 53 & 53 & 53 & P, BG \& $\mathrm{O}$ assumed $64 \%$ recovery \\
\hline Burma & 2 & $125-188$ & 1 & 1 & 1 & P, BG \& O assumed $64 \%$ recovery \\
\hline Canada & $3-15$ & & 3 & 3 & 11 & \\
\hline Collingwood & $0-12$ & $<30^{\mathrm{e}}$ & 0 & 0 & 8 & $\begin{array}{l}\text { P \& BG: grade too low } \\
\text { O: } 64 \% \text { recovery assumed }\end{array}$ \\
\hline Rest & 3 & $20-140^{\mathrm{e}}$ & 3 & 3 & 3 & $\mathrm{P}, \mathrm{BG} \& \mathrm{O}$ assumed $64 \%$ recovery \\
\hline China & $\sim 330^{\mathrm{f}}$ & $\sim 70-80^{\mathrm{f}}$ & 220 & 220 & 220 & P, BG \& $\mathrm{O}$ assumed $64 \%$ recovery \\
\hline Egypt & 6 & $79-188$ & 0 & 3.8 & 3.8 & $\begin{array}{l}\text { P, resource not exploited } \\
\text { BG \& O assumed } 64 \% \text { recovery }\end{array}$ \\
\hline Estonia & 16 & $>183$ & 10 & 10 & 10 & $\mathrm{P}, \mathrm{BG} \& \mathrm{O}$ assumed $64 \%$ recovery \\
\hline France & 7 & $70-100$ & 4.5 & 4.5 & 4.5 & $\mathrm{P}, \mathrm{BG} \& \mathrm{O}$ assumed $64 \%$ recovery \\
\hline FSU ex. Estonia & 278 & $>92^{g}$ & 178 & 178 & 178 & P, BG \& O assumed $64 \%$ recovery \\
\hline Germany & 2 & $?$ & 1 & 1 & 1 & P, BG \& $\mathrm{O}$ assumed $64 \%$ recovery \\
\hline Israel & 4 & $60-71^{\mathrm{d}}$ & 3 & 3 & 3 & P, BG \& $\mathrm{O}$ assumed $64 \%$ recovery \\
\hline $\begin{array}{l}\text { Italy } \\
\end{array}$ & $14-180$ & & 2 & 9 & 115 & \\
\hline Sicily & $4-170^{\mathrm{h}}$ & $8-125^{\mathrm{i}}$ & 2 & 2 & 108 & $\begin{array}{l}\text { P, BG: assumed } 64 \% \text { recovery of } 4 \mathrm{~Gb} \\
\text { O: } 64 \% \text { recovery of } 170 \mathrm{~Gb}\end{array}$ \\
\hline Rest & $10^{\mathrm{j}}$ & $?$ & 0 & 7 & 7 & $\begin{array}{l}\text { P, assumed not exploited } \\
\text { BG \& O assumed } 64 \% \text { recovery }\end{array}$ \\
\hline Jordan & 34 & $75-100^{\mathrm{d}}$ & 22 & 22 & 22 & P, BG \& O assumed $64 \%$ recovery \\
\hline Morocco & $37-53^{\mathrm{k}}$ & $50-70$ & 24 & 34 & 34 & $\begin{array}{l}\text { P assumed } 64 \% \text { recovery of } 37 \mathrm{~Gb} \\
\text { BG \& O assumed } 64 \% \text { recovery of } 53 \mathrm{~Gb}\end{array}$ \\
\hline Sweden & 6 & & 0 & 0 & 0 & assumed to be Uranium source rock \\
\hline Thailand & 6 & $37-168$ & 4 & 4 & 4 & P, BG \& O assumed $64 \%$ recovery \\
\hline Turkey & 2 & $\sim 60^{1}$ & 1 & 1 & 1 & P, BG \& O assumed $64 \%$ recovery \\
\hline UK & 4 & 119 & 3 & 3 & 3 & P, BG \& O assumed $64 \%$ recovery \\
\hline USA & $2250-2420$ & & 786 & 1086 & 1496 & \\
\hline Green River & $1500-1800^{\mathrm{m}}$ & 115 & 500 & 800 & 1100 & P, BG, O (Bartis et al., 2005) \\
\hline E. Devonian & 189 & 50 & 121 & 121 & 121 & $\mathrm{P}, \mathrm{BG} \&, \mathrm{O}$ assumed $64 \%$ recovery \\
\hline Phosphoria & 250 & 83 & 160 & 160 & 160 & P, BG \& O assumed $64 \%$ recovery \\
\hline Heath & $7-180^{\mathrm{n}}$ & 48 & 5 & 5 & 115 & $\begin{array}{l}\mathrm{P} \& \mathrm{BG} \text { assumed } 64 \% \text { of } 7 \mathrm{~Gb} \\
\mathrm{O} \text { assumed } 64 \% \text { of } 180 \mathrm{~Gb}\end{array}$ \\
\hline Elko & 0.2 & ? & 0 & 0 & 0 & Too small \\
\hline Zaire & 100 & $183 ?$ & 0 & 64 & 64 & $\begin{array}{l}\mathrm{P} \text { assumed not exploited } \\
\text { BG \& } \mathrm{O} \text { assumed } 64 \%\end{array}$ \\
\hline Rest & $<3$ & & 0 & 0 & 0 & \\
\hline World & $2900-5580$ & & 1340 & 1730 & 2450 & \\
\hline
\end{tabular}

${ }^{a}$ Russell (1990) unless stated otherwise

${ }^{\mathrm{b}}$ Dyni (2003) unless stated otherwise

${ }^{\mathrm{c}}$ Dyni (2003); Cane (1979)

d Dyni (2003)

${ }^{e}$ Dyni (2003); Russell (1990)

${ }^{\mathrm{f}}$ Liu et al. (2007)

$\mathrm{g}_{\text {data for part of resource }}$

${ }^{\mathrm{h}}$ Russell (1990); Broquet et al. (1984)

${ }^{\mathrm{i}}$ Dyni (1988)

${ }^{\mathrm{j}}$ Russell (1990)

${ }^{\mathrm{k}}$ Dyni (2003); Bekri (1992)

${ }^{1}$ Sener et al. (1995)

${ }^{m}$ Bartis et al. (2005)

${ }^{\mathrm{n}}$ Dyni (2003); Derkey et al. (1985) 
Table 4: Natural Bitumen (In-Situ model) - URR and Start Years

\begin{tabular}{||l|l|l|l|l|l|l||}
\hline \multirow{2}{*}{ Country } & \multicolumn{3}{|c|}{ URR Gb } & \multicolumn{3}{c||}{ Start year } \\
\cline { 2 - 7 } & P & BG & O & P & BG & O \\
\hline Canada & 300 & 300 & 600 & 1978 & 1978 & 1978 \\
Nigeria & 2 & 3 & 3 & 2012 & 2015 & 2025 \\
USA & 4 & 5 & 6 & 2015 & 2013 & 2025 \\
\hline
\end{tabular}


Table 5: Extra Heavy Oil (In-Situ model) - URR, and Start Years

\begin{tabular}{||l|l|l|l|l|l|l||}
\hline \multirow{2}{*}{ Country } & \multicolumn{3}{|c|}{ URR Gb } & \multicolumn{3}{c||}{ Start year } \\
\cline { 2 - 7 } & P & BG & O & P & BG & O \\
\hline China & 1.3 & 1.3 & 1.3 & 2010 & 2013 & 2025 \\
UK & 1 & 1.5 & 2 & 2015 & 2018 & 2030 \\
Venezuela & 250 & 300 & 400 & 1975 & 1975 & 1975 \\
\hline
\end{tabular}


Table 6: Natural Bitumen (Mining model) - URR, Start Years, Max Production and Mine Life

\begin{tabular}{|c|c|c|c|c|c|c|c|c|c|c|c|c|}
\hline \multirow[t]{2}{*}{ Country } & \multicolumn{3}{|c|}{$\begin{array}{l}\text { URR } \\
(\mathrm{Gb})\end{array}$} & \multicolumn{3}{|c|}{ Start year } & \multicolumn{3}{|c|}{$\begin{array}{l}\text { Max Production } \\
\text { (Gb/y) }\end{array}$} & \multicolumn{3}{|c|}{$\begin{array}{l}\text { Mine Life } \\
\text { (v) }\end{array}$} \\
\hline & $\mathrm{P}$ & BG & $\mathrm{O}$ & $\mathrm{P}$ & $\mathrm{BG}$ & $\mathrm{O}$ & $\mathrm{P}$ & $\mathrm{BG}$ & $\mathrm{O}$ & $\mathrm{P}$ & BG & $\mathrm{O}$ \\
\hline Angola & 0.7 & 0.7 & 0.7 & 2020 & 2023 & 2035 & 0.001 & 0.001 & 0.001 & 40 & 40 & 40 \\
\hline Canada & 50 & 50 & 100 & 1967 & 1967 & 1967 & 0.010 & 0.01 & 0.01 & 80 & 80 & 80 \\
\hline China & 0.2 & 0.2 & 0.2 & 2010 & 2013 & 2025 & 0.001 & 0.001 & 0.001 & 40 & 40 & 40 \\
\hline Indonesia & 0.7 & 0.7 & 0.7 & 1990 & 1990 & 1990 & 0.001 & 0.001 & 0.001 & 40 & 40 & 40 \\
\hline Italy & 0.3 & 0.3 & 0.3 & 2017 & 2020 & 2030 & 0.001 & 0.001 & 0.001 & 40 & 40 & 40 \\
\hline Kazakhstan & 63 & 63 & 63 & 2015 & 2018 & 2030 & 0.010 & 0.01 & 0.01 & 80 & 80 & 80 \\
\hline Madagascar & 1 & 3 & 9.8 & 2013 & 2013 & 2015 & 0.001 & 0.005 & 0.005 & 40 & 60 & 80 \\
\hline Nigeria & 2.5 & 3.5 & 3.5 & 2012 & 2015 & 2025 & 0.005 & 0.005 & 0.005 & 60 & 60 & 60 \\
\hline Russia & 10 & 53 & 100 & 2025 & 2025 & 2035 & 0.010 & 0.01 & 0.01 & 80 & 80 & 80 \\
\hline USA & 4 & 6 & 6 & 2015 & 2013 & 2025 & 0.005 & 0.005 & 0.005 & 60 & 60 & 60 \\
\hline
\end{tabular}


Table 7: Shale Oil (Mining model) - URR, Start Years, Max Production and Mine Life

\begin{tabular}{|c|c|c|c|c|c|c|c|c|c|c|c|c|c|}
\hline \multirow[t]{2}{*}{ Country } & & \multicolumn{3}{|c|}{$\begin{array}{l}\text { URR } \\
(\mathrm{Gb})\end{array}$} & \multicolumn{3}{|c|}{ Start year } & \multicolumn{3}{|c|}{$\begin{array}{c}\text { Max Production } \\
(\mathrm{Gb} / \mathrm{y})\end{array}$} & \multicolumn{3}{|c|}{$\begin{array}{l}\text { Mine Life } \\
(y)\end{array}$} \\
\hline & & $\mathrm{P}$ & BG & $\mathrm{O}$ & $\mathrm{P}$ & $\mathrm{BG}$ & $\mathrm{O}$ & $\mathrm{P}$ & $\mathrm{BG}$ & $\mathrm{O}$ & $\mathrm{P}$ & BG & $\mathrm{O}$ \\
\hline \multirow[t]{3}{*}{ Australia } & & 24 & 34 & 224 & & & & & & & & & \\
\hline & Toolebuc & 0 & 10 & 200 & & 2050 & 2050 & & 0.01 & 0.01 & & 80 & 80 \\
\hline & Rest & 24 & 24 & 24 & 2015 & 2013 & 2025 & 0.01 & 0.01 & 0.01 & 80 & 80 & 80 \\
\hline Brazil & & 53 & 53 & 53 & 2004 & 2004 & 2004 & 0.01 & 0.01 & 0.01 & 80 & 80 & 80 \\
\hline Burma & & 1 & 1 & 1 & 2020 & 2023 & 2035 & 0.001 & 0.001 & 0.001 & 40 & 40 & 40 \\
\hline \multirow[t]{3}{*}{ Canada } & & 3 & 3 & 11 & & & & & & & & & \\
\hline & Collingwood & 0 & 0 & 8 & & & 2030 & & & 0.005 & & & 60 \\
\hline & Rest & 3 & 3 & 3 & 2015 & 2018 & 2030 & 0.005 & 0.005 & 0.005 & 60 & 60 & 60 \\
\hline China & & 220 & 220 & 220 & 2004 & 2004 & 2004 & 0.01 & 0.01 & 0.01 & 80 & 80 & 80 \\
\hline Egypt & & 0 & 4 & 4 & & 2018 & 2030 & & 0.005 & 0.005 & & 60 & 60 \\
\hline Estonia & & 10 & 10 & 10 & 2004 & 2004 & 2004 & 0.01 & 0.01 & 0.01 & 80 & 80 & 80 \\
\hline France & & 5 & 5 & 5 & 2015 & 2023 & 2030 & 0.005 & 0.005 & 0.005 & 60 & 60 & 60 \\
\hline $\begin{array}{l}\text { FSU } \\
\text { ex. Estonia }\end{array}$ & & 178 & 178 & 178 & 2020 & 2020 & 2030 & 0.01 & 0.01 & 0.01 & 80 & 80 & 80 \\
\hline Germany & & 1 & 1 & 1 & 2015 & 2018 & 2030 & 0.001 & 0.001 & 0.001 & 40 & 40 & 40 \\
\hline Israel & & 3 & 3 & 3 & 2015 & 2018 & 2030 & 0.005 & 0.005 & 0.005 & 60 & 60 & 60 \\
\hline \multirow[t]{3}{*}{ Italy } & & 2 & 9 & 115 & & & & & & & & & \\
\hline & Sicily & 2 & 2 & 108 & 2020 & 2023 & 2035 & 0.005 & 0.005 & 0.01 & 60 & 60 & 80 \\
\hline & Rest & 0 & 7 & 7 & & 2023 & 2035 & & 0.005 & 0.005 & & 60 & 60 \\
\hline Jordan & & 22 & 22 & 22 & 2015 & 2018 & 2030 & 0.01 & 0.01 & 0.01 & 80 & 80 & 80 \\
\hline Morocco & & 24 & 34 & 34 & 2015 & 2018 & 2030 & 0.01 & 0.01 & 0.01 & 80 & 80 & 80 \\
\hline Thailand & & 4 & 4 & 4 & 2015 & 2018 & 2030 & 0.005 & 0.005 & 0.005 & 60 & 60 & 60 \\
\hline Turkey & & 1 & 1 & 1 & 2015 & 2018 & 2030 & 0.001 & 0.001 & 0.001 & 40 & 40 & 40 \\
\hline UK & & 3 & 3 & 3 & 2015 & 2018 & 2030 & 0.005 & 0.005 & 0.005 & 60 & 60 & 60 \\
\hline \multirow[t]{5}{*}{ USA } & & 786 & 1086 & 1496 & & & & & & & & & \\
\hline & Green River & 500 & 800 & 1100 & 2015 & 2012 & 2012 & 0.01 & 0.01 & 0.01 & 80 & 80 & 80 \\
\hline & Devonian & 121 & 121 & 121 & 2020 & 2023 & 2035 & 0.01 & 0.01 & 0.01 & 80 & 80 & 80 \\
\hline & Phosphoria & 160 & 160 & 160 & 2020 & 2023 & 2035 & 0.01 & 0.01 & 0.01 & 80 & 80 & 80 \\
\hline & Heath & 5 & 5 & 115 & 2020 & 2023 & 2035 & 0.005 & 0.01 & 0.005 & 60 & 60 & 80 \\
\hline Zaire & & 0 & 64 & 64 & & 2023 & 2035 & & 0.01 & 0.01 & & 80 & 80 \\
\hline
\end{tabular}




\section{A. Maximum production for Green River deposit}

By analyzing the long term allocations for Upper Colorado basin states from U.S. Department of the Interior (2005) it is concluded that if upper Colorado basin states allocations are at $6 \mathrm{Maf} / \mathrm{y}$ (million acre-feet per year), then, by 2050, there will be essentially no free water available for oil shale processes. If water flow rates return to higher levels then the Upper Colorado Basin states allocation will rise, alternatively legal action may occur to ensure that water allocations for the Upper and Lower Colorado basins are once again equalized. Further water could be pumped to the Upper Colorado basin from other basins. The Pessimist case will assume that upper Colorado allocations are at approximately $6 \mathrm{Maf} / \mathrm{y}$ and little water is sourced from other basins, hence a water usage of $0.1 \mathrm{Maf} / \mathrm{y}$ will be assumed. The Best Guess will assume that $0.8 \mathrm{Maf} / \mathrm{y}$ of water is available, through a water allocation of more than $6 \mathrm{Maf} / \mathrm{y}$ and pipelines from other basins. The Optimists case will assume that $1.5 \mathrm{Maf} / \mathrm{y}$ of water is available. To provide perspective on the very optimistic assumption assumed for the Optimists case, Edmonton in Canada has a population of around 900,000 people and consumes 0.1 Maf/y (Griffiths et al., 2006).

In all cases it is assumed that 2 barrels of water are needed to provide 1 barrel of oil (which includes the amount of water necessary for the significantly increased population). Also uncertain is the amount of water necessary for the Shell in-situ process, and to a lesser degree surface mining. It is assumed that in-situ processes dominate, as in-situ processes are assumed to consume significantly less water than mining methods. Given the Shell in-situ method generates 1/3 gas (Shell, 2007) and Bartis et al. (2005) indicates that roughly all of the gas is needed to generate the electricity for the process. It is concluded that the Pessimist case will have a maximum production of $0.3 \mathrm{~Gb} / \mathrm{y}(0.7 \mathrm{Mb} / \mathrm{d})$ the Best Guess has a max production of $2 \mathrm{~Gb} / \mathrm{y}(5.7 \mathrm{Mb} / \mathrm{d})$ and the Optimist case has $4 \mathrm{~Gb} / \mathrm{y}(10.7 \mathrm{Mb} / \mathrm{d})$. It should be stated that water supplies in the Upper Colorado Basin are far from certain, and it is likely that even without an oil shale industry a lack of water will be a major issue for these states. 